\title{
In-Tank Processes for Destruction of Organic Complexants and Removal of Selected Radionuclides
}

Prepared for the U.S. Department of Energy Office of Environmental Restoration and Waste Management

\section{(2) Westinghouse Hanford Company Richland, Washington}

Hanford Operations and Engineering Contractor for the

U.S. Department of Energy under Contract DE-AC06-87RL10930

Approved for Public Release

DISTAIBUTION OF THIS DOCUMENT IS UNLIMITED 


\section{DISCLAIMER}

Portions of this document may be illegible in electronic image products. Images are produced from the best available original document. 


\section{In-Tank Processes for Destruction of Organic Complexants and Removal of Selected Radionuclides}

Prepared for the U.S. Department of Energy Office of Environmental Restoration and Waste Management

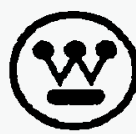
Westinghouse Hanford Company Richland, Washington

Hanford Operations and Engineering Contractor for the U.S. Department of Ehergy under Contract DE-AC06-87RL10930 
DISTRIBUTION SHEET

\begin{tabular}{|c|c|c|c|c|c|}
\hline \multirow{2}{*}{$\begin{array}{l}\text { To } \\
\text { Distribution }\end{array}$} & \multirow{2}{*}{\multicolumn{3}{|c|}{\begin{tabular}{|l} 
From \\
M. J. Kupfer
\end{tabular}}} & \multicolumn{2}{|c|}{ Page 1 of 2} \\
\hline & & & & \multicolumn{2}{|c|}{ Date $03 / 10 / 95$} \\
\hline \multirow{2}{*}{\multicolumn{4}{|c|}{$\begin{array}{l}\text { Project Title/Work Order } \\
\text { WHC-SD-WM-ES-321, Rev. 0, In-Tank Processes for Destruction of } \\
\text { Organic Complexants and Removal of Selected Radionuclides }\end{array}$}} & \multirow{2}{*}{\multicolumn{2}{|c|}{$\begin{array}{l}\text { EDT No. } 611574 \\
\text { ECN No. }\end{array}$}} \\
\hline & & & & & \\
\hline Name & MSIN & $\begin{array}{l}\text { Text } \\
\text { With Al1 } \\
\text { Attach. }\end{array}$ & $\begin{array}{l}\text { Text } \\
\text { Oniy }\end{array}$ & $\begin{array}{l}\text { Attach./ } \\
\text { Appendix } \\
\text { Only }\end{array}$ & $\begin{array}{c}\text { EDT/ECN } \\
\text { Only }\end{array}$ \\
\hline $\begin{array}{l}\text { Central Files }(c r i c .+1) \\
\text { OSTI }(2) \\
\text { J. N. Appe1 } \\
\text { S. K. Baker } \\
\text { A. L. Boldt } \\
\text { K. D. Boomer } \\
\text { P. J. Certa } \\
\text { J. M. Conner } \\
\text { K. M. Eager } \\
\text { R. R. Gadd } \\
\text { J. S. Garfield } \\
\text { K. A. Gasper } \\
\text { C. M. Haegen (5) } \\
\text { D. L. Herting } \\
\text { M. E. Johnson } \\
\text { N. W. Kirch } \\
\text { R. A. Kirkbride } \\
\text { M. J. Klem } \\
\text { M. J. Kupfer (5) } \\
\text { G. T. Maclean. } \\
\text { R. J. Murkowski } \\
\text { R. M. Orme } \\
\text { W. A. Peiffer } \\
\text { D. L. Penwe11 } \\
\text { J. C. Person } \\
\text { R. W. Powel1 } \\
\text { G. W. Reddick } \\
\text { I. E. Reep } \\
\text { L. W. Shelton } \\
\text { J. P. Sloughter } \\
\text { L. M. Swanson } \\
\text { J. A. Swenson } \\
\text { D. J. Washenfelder } \\
\text { G. F. Williamson } \\
\text { T. L. Yount }\end{array}$ & $\begin{array}{l}\text { L8-04 } \\
\text { L8-07 } \\
\text { G3-21 } \\
H 5-57 \\
H 5-49 \\
H 5-49 \\
H 5-27 \\
H 5-27 \\
H 5-27 \\
\text { G3-20 } \\
\text { H5-49 } \\
\text { G3-21 } \\
\text { G3-21 } \\
\text { T6-09 } \\
\text { B1-58 } \\
\text { R2-11 } \\
H 5-27 \\
H 5-27 \\
H 5-49 \\
H 5-49 \\
\text { G6-13 } \\
\text { H5-27 } \\
\text { H5-49 } \\
\text { H5-27 } \\
\text { T6-09 } \\
\text { G3-21 } \\
\text { H5-49 } \\
\text { G3-21 } \\
H 5-49 \\
\text { T6-07 } \\
H 5-49 \\
H 5-49 \\
H 5-27 \\
\text { G6-13 } \\
\text { G3-20 }\end{array}$ & $\begin{array}{l}x \\
x \\
x \\
x \\
x \\
x \\
x \\
x \\
x \\
x \\
x \\
x \\
x \\
x \\
x \\
x \\
x \\
x \\
x \\
x \\
x \\
x \\
x \\
x \\
x \\
x \\
x \\
x \\
x \\
x \\
x \\
x \\
x \\
x \\
x\end{array}$ & & & \\
\hline
\end{tabular}




\section{DISTRIBUTION SHEET (continued)}

\begin{tabular}{|c|c|c|c|c|c|}
\hline \multirow{2}{*}{$\begin{array}{l}\text { To } \\
\text { Distribution }\end{array}$} & \multirow{2}{*}{\multicolumn{3}{|c|}{$\begin{array}{l}\text { From } \\
\text { M. J. Kupfer }\end{array}$}} & \multicolumn{2}{|c|}{ Page 2 of 2} \\
\hline & & & & \multicolumn{2}{|c|}{ Date $03 / 10 / 95$} \\
\hline \multicolumn{4}{|c|}{ Project Title/Work Order } & \multicolumn{2}{|c|}{ EDT No. 611574} \\
\hline \multicolumn{4}{|c|}{$\begin{array}{l}\text { WHC-SD-WM-ES-321, Rev. 0, In-Tank Processes for Destruction of } \\
\text { Organic Complexants and Removal of Selected Radionuclides- }\end{array}$} & \multicolumn{2}{|l|}{ ECN No. } \\
\hline Name & MSIN & $\begin{array}{c}\text { Text } \\
\text { With A11 } \\
\text { Attach. }\end{array}$ & $\begin{array}{l}\text { Text } \\
\text { OnTy }\end{array}$ & $\begin{array}{l}\text { Attach./ } \\
\text { Appendix } \\
\text { Only }\end{array}$ & $\begin{array}{l}\text { EDT/ECN } \\
\text { Only }\end{array}$ \\
\hline
\end{tabular}

BNFL

M. M. McKeon

G3-02 $X$

$\mathrm{DOE} / \mathrm{RL}$

S. T. Burnum

P. T. Furlong

R. A. Gilbert

P. E. Lamont

D. D. Wodrich

S7-53

G3-20

S7-53

$57-53$

S7-50

$X$
$X$
$X$
$X$
$X$

PNL

N. G. Colton

K3-75

L. K. Holton, Jr.

$\mathrm{K} 9-73$

W. G. Richmond

J. T. Slankas

K6-51

K9-81

J. L. Swanson

P7-25

$X$
$X$
$X$
$X$
$X$

$W^{2} S$ Company

W. W. Schu1z, W $W^{2} S$ Company

5314 Arbustos Court

ATbuquerque, NM 87111 


\title{
RELEASE AUTHORIZATION
}

\author{
Document Number: HHC-SD-HM-ES-321, Rev. 0
}

Document Title: In-Tank Processes for Destruction of Organic

Complexants and Removal of Selected Radionuclides

Release Date: $\quad 4 / 17 / 95$

This document was reviewed following the
procedures described in WHC-CM-3-4 and is:

APPROVED FOR PUBLIC RELEASE

WHC Information Release Administration Specialist:
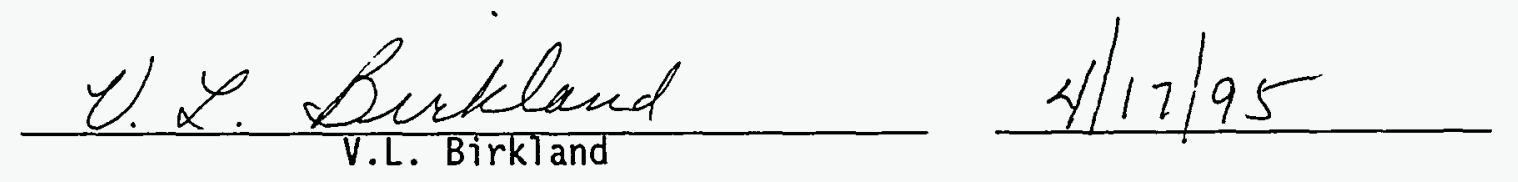

TRADEMARK DISCLAIMER. Reference herein to any specific commercial product, process, or service by trade name, trademark, manufacturer, or otherwise, does not necessarily constitute or imply its endorsement, recomendation, or favoring by the United States Government or any agency thereof or its contractors or subcontractors.

This report has been reproduced from the best available copy. Available in paper copy and microfiche. Printed in the United States of America. Available to the U.S. Department of Energy and its contractors from:

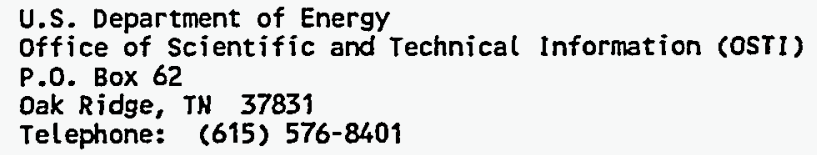

U.S. Department of Cormerce National Technical Information Service (NTIS) 5285 Port Royal Road

Springfield, VA 22161

Telephone: '(703) 487-4650

\section{DISCLAIMER}

This report was prepared as an account of work sponsored by an agency of the United States Government. Neither the United States Government nor any agency thereof, nor any of their employees, makes any warranty, express or implied, or assumes any legal liability or responsibility for the accuracy, completeness, or usefulness of any information, apparatus, product, or process disclosed, or represents that its use would not infringe privately owned rights. Reference herein to any specific commercial product, process, or service by trade name, trademark, manufacturer, or otherwise does not necessarily constitute or imply its endorsement, recommendation, or favoring by the United States Government or any agency thereof. The views and opinions of authors expressed herein do not necessarily state or reflect those of the United States Government or any agency thereof. 
2. To: (Receiving Organization)

TWRS Process Design

5. Proj./Prog./Dept./Div.:

TWRS, 71320

8. Originator Remarks:

Approval/Release
3. From: (Originating Organization)

TWRS Process Engineering

6. Cog. Engr.:

M. J. Kupfer, 376-6631
4. Related EDT No.:

N/A

7. Purchase Order No.:

N/A

9. Equip./Component No.:

N/A

10. System/Bldg./Facility:

N/A

12. Major Assm. Dwg. No.:

N/A

13. Permit/Permit Application No.:

$\mathrm{N} / \dot{\mathrm{A}}$

14. Required Response Date:

N/A

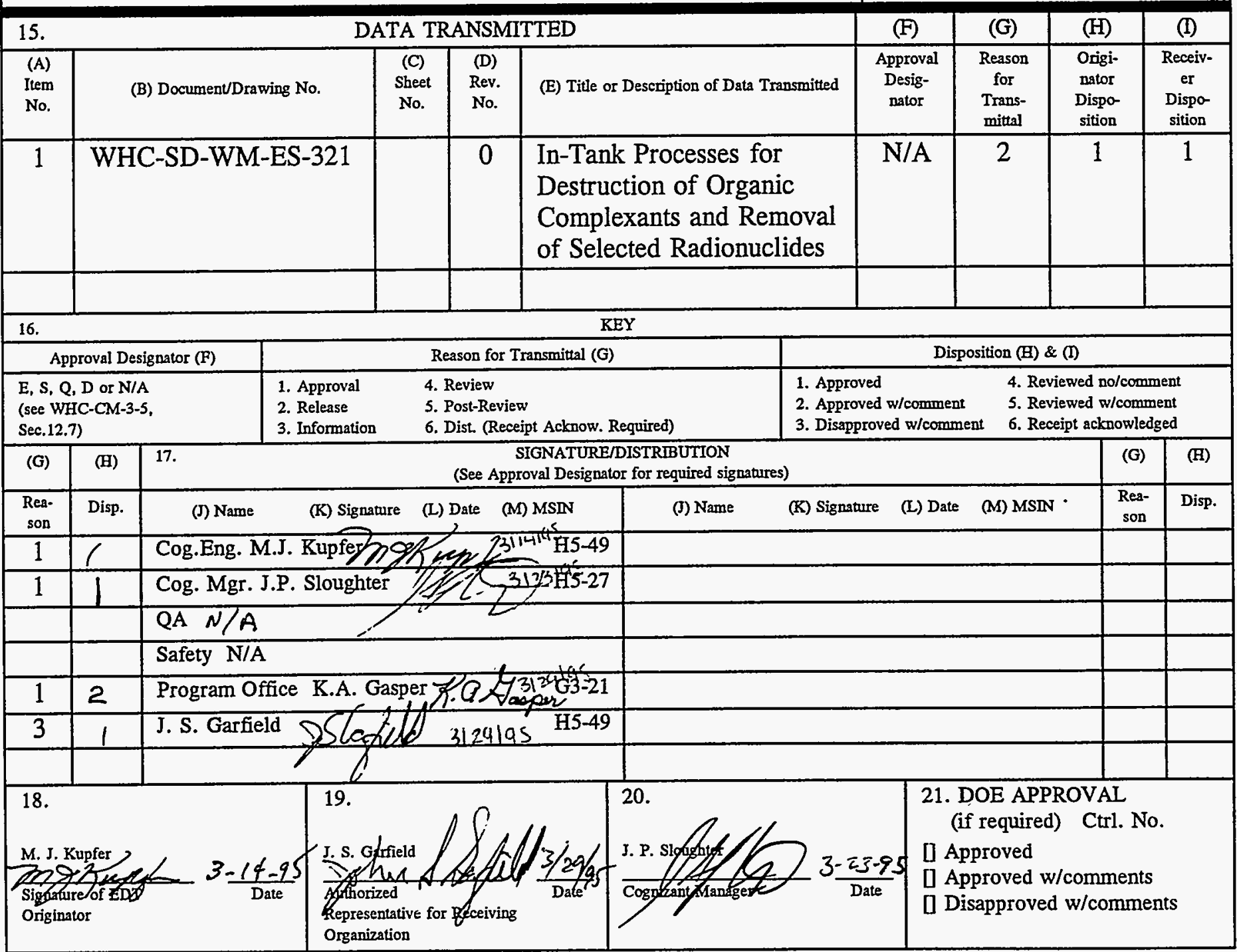


2. Title

In-Tank Processes for Destruction of Organic Complexants and Removal of Selected Radionuclides

5. Key Words

High-Level Waste

Low-Leve1 Waste

Organic

Pretreatment

3. Number

WHC-SD-WM-ES-321

4. Rev No.

0
6. Author

Name: M. J. Kupfer

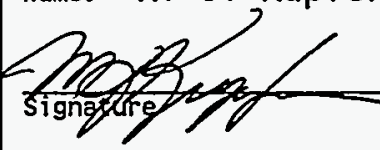

Organization/Charge code $7 / 320 / 15 \mathrm{c} 72$

7. Abstract

This report establishes the need and technical feasibility for using in-tank pretreatment processes for destruction of organic complexants and removal of ${ }^{90} \mathrm{Sr}$, transuranic (TRU) elements, and ${ }^{99} \mathrm{Tc}$ from double-she11 tank (DST) liquid wastes.

Neither ${ }^{90} \mathrm{Sr}$ nor ${ }^{99} \mathrm{Tc}$ have to be removed from any DST solution to obtain vitrified product containing less than the Nuclear Regulatory Commission (NRC) criteria for Class C commercial low-7evel waste (LLW). To meet the NRC criterion for Class C LLW, TRU elements must be removed from liquid wastes in three (possibly five) DSTs.

No ${ }^{90} \mathrm{Sr}$ will have to be removed from any solution for the total vitrified waste from both DSTs and single-shell tanks to meet a goal of $<7 \mathrm{MCj}$ of radionuclides and a NRC ruling for Hanford Site Incidental Waste.

Guidance from ALARA principles and the TWRS Environmental Impact Statement may dictate additional removal of radionuclides from DST supernatant liquids.

Scavenging processes involving precipitation of strontium phosphate and/or hydrated iron oxide effectively remove ${ }^{90} \mathrm{Sr}$ and/or TRU elements from actual DST wastes including complexant concentrate (CC) wastes. Destruction of organic complexants is not required for these scavenging processes to reduce the ${ }^{90} \mathrm{Sr}$ and/or TRU element concentrations of DST waste solutions to or below the NRC criteria for Class C commercial LLW. However, substantially smaller amounts of scavenging agents would be required for removal of ${ }^{90} \mathrm{Sr}$ and TRU elements from $\mathrm{CC}$ waste if organic complexants were destroyed. Low concentrations of added $\mathrm{Sr}\left(\mathrm{NO}_{3}\right)_{2}$ and $\mathrm{Fe}\left(\mathrm{NO}_{3}\right)_{3}$ are desirable to minimize the volume of HLW glass.

8. RELEASE STAMP

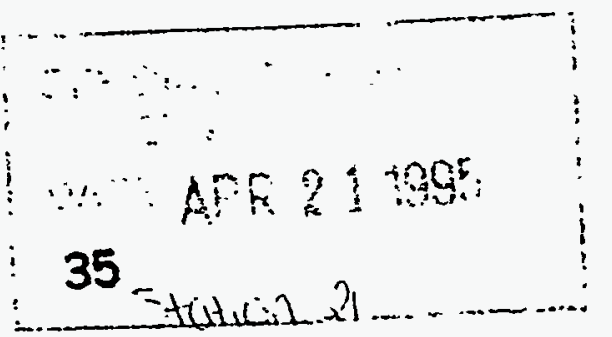


Revision 0

\section{IN-TANK PROCESSES FOR DESTRUCTION OF ORGANIC COMPLEXANTS AND REMOVAL OF SELECTED RADIONUCLIDES}

February 1995

W. W. Schulz

M. J. Kupfer

M. M. McKeon

Prepared for

Westinghouse Hanford Company

Richland, Washington 


\section{WHC-SD-WM-ES-321}

Revision 0

\section{ACKNOWLEDGEMENTS}

We are deeply indebted to L. W. Shelton of Westinghouse Hanford Company for all his help and assistance in providing us with chemical and radionuclide inventories in the double-shell tanks. We are also grateful to A. L. Boldt, K. D. Boomer, and J. S. Garfield of Westinghouse Hanford Company for their counsel and guidance during preparation of several drafts of this report. 
WHC-SD-WM-ES-321

Revision 0

\section{EXECUTIVE SUMMARY}

A key element in the present Tank Waste Remediation System Technical Strategy for disposal of double-shell tank (DST) wastes is to determine the need and technical feasibility of destruction of organic complexants and removal of ${ }^{90} \mathrm{Sr}$, transuranic (TRU) elements, and possibly ${ }^{99} \mathrm{Tc}$. This report establishes the need for pretreatment processes for DST liquid waste, critically reviews existing in-tank pretreatment technology and processes, and recommends essential follow-on tests to fill technology gaps. The need, if any, for pretreatment of the water-soluble fraction of single-shell tanks is not addressed in this report.

\section{Need For In-Tank Pretreatment Processing ${ }^{1}$}

Neither ${ }^{90} \mathrm{Sr}$ nor ${ }^{99} \mathrm{Tc}$ have to be removed from any DST solution to obtain vitrified product containing less than the U.S. Nuclear Regulatory Commission (NRC) criteria for Class C commercial low-level waste (LLW). To meet the NRC criterion for Class C LLW, TRU elements must be removed (Decontamination Factor [DF] of 1.4 to 7.6) from liquid wastes in three (possibly five) DSTs.

${ }^{1}$ Findings and conclusions stated in this report are based upon the currently available knowledge of the composition of the liquid wastes in each of the 28 DSTs. Composition data cited in this report for supernatants include not only those components presently in DST supernatant liquids but also include conservative estimates of quantities of radionuclides which could be solubilized during retrieval and sludge washing operations. Some changes in the composition database will surely occur as the result of further sampling and analysis of the DST liquid waste. It is anticipated, however, that these changes will be small and will not alter the major conclusions and findings stated in this report. 


\section{WHC-SD-WM-ES-321 \\ Revision 0}

To be classified as Incidental Waste, the total radionuclide content of the glass produced from DSTs and single-shell tanks (SSTs) for onsite disposal should not exceed 2-3 percent of the total inventory generated from reprocessing the spent nuclear fuel (i.e., approximately $7 \mathrm{MCi}$ total radionuclides). Based on this proposed criterion, ${ }^{90} \mathrm{Sr}$ will not have to be removed from any DST or SST waste.

Destruction of organic complexants and/or their degradation products in complex concentrate (CC) wastes is judged not necessary to accomplish efficient ion exchange removal of ${ }^{137} \mathrm{Cs}$. Some concerns have been expressed that organic material in CC wastes might, by fouling or other mechanisms, interfere with sorption and/or elution of ${ }^{137} \mathrm{Cs}$.

Destruction of organic material in CC wastes is also judged not necessary for satisfactory vitrification of $L L W$ in combustion-type melters. However, for vitrification of LLW in Joule-heated melters, destruction of organic materials may be necessary to prevent occurrence of deleterious metal reduction reactions.

Guidance from As-Low-As-Reasonably-Achievable (ALARA) principles and the Tank Waste Remediation System Environmental Impact Statement may dictate additional removal of radionuclides from DST supernatant liquids.

Scavenging processes involving precipitation of strontium phosphate and/or hydrated iron oxide effectively remove ${ }^{90} \mathrm{Sr}$ and/or TRU elements from actual DST wastes including $C C$ 
WHC-SD-WM-ES-321

Revision 0

wastes. Indeed, destruction of organic complexants is not required for these scavenging processes to reduce the ${ }^{90} S r$ and/or TRU element concentrations of DST waste solutions to or below the NRC criteria for Class C commercial LLW. However, substantially smaller amounts of scavenging agents would be required for removal of ${ }^{90} \mathrm{Sr}$ and TRU elements from $\mathrm{CC}$ waste if organic complexants were destroyed. Low concentrations of added $\mathrm{Sr}\left(\mathrm{NO}_{3}\right)_{2}$ and $\mathrm{Fe}\left(\mathrm{NO}_{3}\right)_{3}$ are desirable to minimize the volume of $\mathrm{HLW}$ glass. No technology for removal of ${ }^{99} \mathrm{Tc}$ by precipitation from Hanford Site waste solutions has been demonstrated. However, work at other U.S. Department of Energy sites indicate precipitation techniques may be technically feasible.

Under some scenarios, organic complexants in CC wastes would likely need to be destroyed to meet desired ALARA guidelines.

Status of In-Tank Pretreatment Technology

${ }^{90} \mathrm{Sr}$ is effectively removed from both $\mathrm{CC}$ wastes (95 percent removal) and non-CC-type DST waste (99 percent removal) by addition of nonradioactive $\mathrm{Sr}\left(\mathrm{NO}_{3}\right)_{2}$ to precipitate $\mathrm{Sr}_{3}\left(\mathrm{PO}_{4}\right)_{2}$. Precipitation of $\mathrm{Fe}_{2} \mathrm{O}_{3} \cdot \times \mathrm{H}_{2} \mathrm{O}$ from $\mathrm{CC}$ waste removes 84 to 96 percent of the ${ }^{241} \mathrm{Am}$ and 60 to 75 percent of the soluble plutonium. 


\section{WHC-SD-WM-ES-321}

Revision 0

No demonstrated technology exists for in-tank precipitation removal of ${ }^{99} \mathrm{Tc}$ from $\mathrm{DST}$ waste solutions. Candidate precipitation forms include $T c_{2} S_{7}$ and tetraphenylphosphonium pertechnetate.

Very preliminary bench-scale tests of prolonged heating of actual CC waste solutions at $100{ }^{\circ} \mathrm{C}$ have been performed. This "heat and digest" process clearly oxidized organic matter, but present data are not sufficient either to establish exactly which organic complexants are attacked or to establish the effects of prolonged digestion at elevated temperature upon removal of ${ }^{90} \mathrm{Sr}$ and/or TRU elements.

\section{Recommended Follow-On Experimental Work}

Lack of more extensive bench-scale data from tests with actual DST wastes greatly hampers evaluation and selection of feasible technology for in-tank application. Important recommended follow-on experimental tasks include the following:

- Investigate removal of ${ }^{90} \mathrm{Sr}$ and TRU elements from liquid wastes in all CC tanks and from waste solutions from a representative number (e.g., 5 to 10) other DSTs by precipitation of strontium phosphate and hydrated iron oxide. 
WHC-SD-WM-ES-321

Revision 0

- Perform tests to establish the technical viability of in-tank precipitation of $T c_{2} S_{7}$ and tetraphenylphosphonium pertechnetate from DST wastes as a means of reducing the ${ }^{99} T c$ concentration of such wastes.

- Continue and complete "heat and digest" tests with CC waste from DST 241-AN-107. Expand the scope of "heat and digest" experiments to solutions from the other three DSTs containing CC waste and to quantitative measurements of the behavior of individual organic complexants as well as ${ }^{90} \mathrm{Sr}$ and TRU elements. 
WHC-SD-WM-ES-321

Revision 0

This page intentionally left blank. 
WHC-SD-WM-ES-321

Revision 0

\section{CONTENTS}

1.0 INTRODUCTION . . . . . . . . . . . . . . . . 1

1.1 DOUBLE-SHELL TANK WASTES $\ldots \ldots \ldots \ldots \ldots \ldots$

1.2 OVERALL TANK WASTE REMEDIATION SYSTEM TECHNICAL STRATEGY $\ldots \ldots \ldots \ldots \ldots \ldots \ldots \ldots \ldots \ldots \ldots \ldots \ldots \ldots \ldots \ldots$

1.3 OBJECTIVES OF THIS REPORT $\ldots \ldots \ldots \ldots \ldots \ldots \ldots \ldots \ldots$

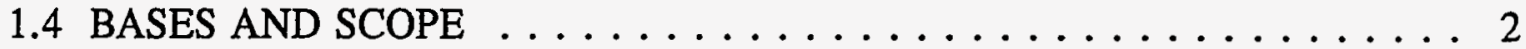

1.5 BACKGROUND INFORMATION $\ldots \ldots \ldots \ldots \ldots \ldots \ldots \ldots$

1.5.1 Double-Shell Tank Waste Remediation System Technical Strategy . . . 3

1.5.2 Source and Composition of Complexed Concentrate Wastes ..... . 5

2.0 SUMMARY AND CONCLUSIONS . . . . . . . . . . . . 9

2.1 NEEDS FOR IN-TANK PRETREATMENT PROCESSES . . . . . . . . . . 9

2.1.1 Removal of Strontium-90, Transuranic Elements, and Technetium-99 . 9

2.1.2 Destruction of Organic Complexants . . . . . . . . . . . . 10

2.2 STATUS OF IN-TANK PRETREATMENT TECHNOLOGY . . . . . . 11

2.2.1 Removal of Strontium-90 and Transuranic Elements . . . . . . . . 11

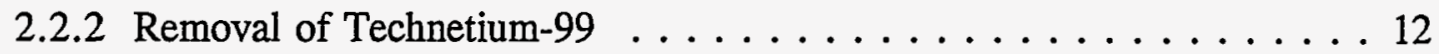

2.2.3 Destruction of Organic Complexants . . . . . . . . . . 12

2.3 RECOMMENDED FOLLOW-ON EXPERIMENTAL WORK $\ldots \ldots \ldots 13$

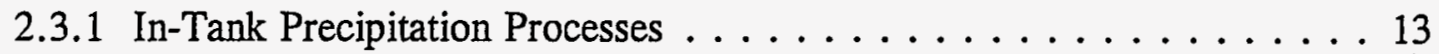

2.3.2 Thermal Destruction of Organic Complexants ........... . 13

2.3.3 Sorption Behavior of Strontium-90, Technetium-99,

and Transuranic Elements . . . . . . . . . . . . . . . 13

3.0 IN-TANK PRETREATMENT PROCESSES NEEDS AND SELECTION

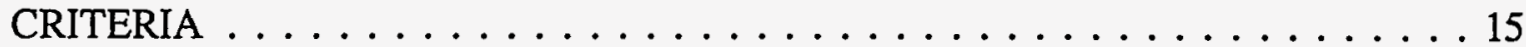

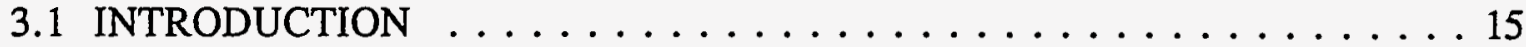

3.2 COMPOSITION OF DOUBLE-SHELL TANK LIQUID WASTES $\ldots \ldots \ldots 15$

3.3 REQUIRED DECONTAMINATION OF RADIONUCLIDES . . . . . . . . 17

3.3.1 U.S. Nuclear Regulatory Commission Class C Waste Criteria . . . . 17

3.3.2 U.S. Nuclear Regulatory Commission Incidental Waste Definition and Criteria . . . . . . . . . . . . . . 24

3.3.3 Lightly Shielded Low-Level Waste Vitrification: Impacts of Feed Strontium-90 Concentration $\ldots \ldots \ldots \ldots 25$

3.3.4 As-Low-As-Reasonably-Achievable Criteria:

Incentives for In-Tank Removal of Technetium-99,

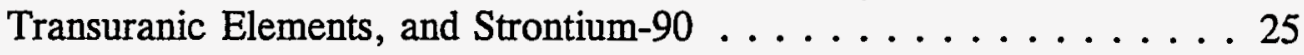

3.4 CESIUM ION EXCHANGE-EFFECT OF ORGANIC COMPLEXANTS . . . . 27

3.5 WASTE VITRIFICATION PROCESSES AND FACILITIES--EFFECTS OF ORGANIC COMPLEXANTS . . . . . . . . . . . . . . . . 29 
WHC-SD-WM-ES-321

Revision 0

4.0 REVIEW AND EVALUATION OF EXISTING EXPERIMENTAL DATA FOR IN-TANK PRETREATMENT OF DOUBLE-SHELL TANK WASTES $\ldots \ldots \ldots 33$

4.1 INTRODUCTION $\ldots \ldots \ldots \ldots \ldots \ldots \ldots \ldots \ldots \ldots \ldots \ldots$

4.2 PRECIPITATION REMOVAL OF STRONTIUM-90 AND TRANSURANIC

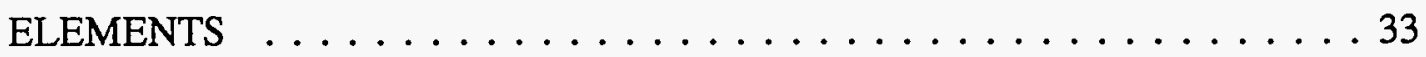

4.2.1 By Metal Hydroxides and Phosphates . . . . . . . . . 33

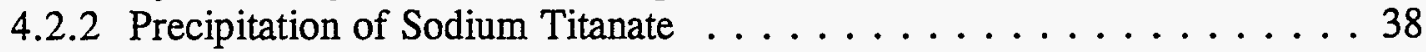

4.3 PRECIPITATION REMOVAL OF TECHNETIUM-99 . . . . . . . . . . . 39

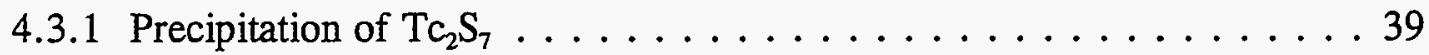

4.3.2 Precipitation of Tetraphenylphosphonium Pertechnetate . . . . . . . 39

4.4 SORPTION REMOVAL OF STRONTIUM-90, TRANSURANIC ELEMENTS, AND TECHNETIUM-99 . . . . . . . . . . . . . . 40

4.4.1 Sorption of Cesium-137, Strontium-90, and Transuranic Elements . . 40

4.4.2 Sorption of Technetium- $99 \ldots \ldots \ldots \ldots \ldots \ldots \ldots$. . . . . . . . . 41

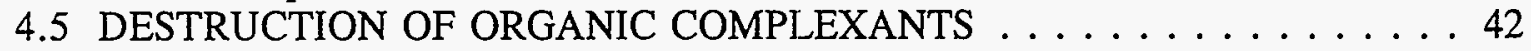

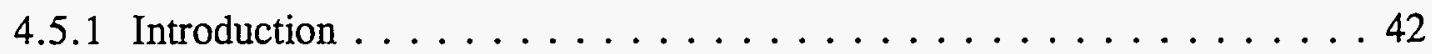

4.5.2 Thermal Destruction of Organic Complexants . . . . . . . . 43

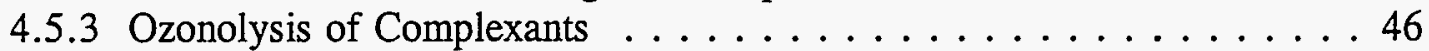

5.0 RECOMMENDED FOLLOW-ON BENCH-SCALE STUDIES . . . . . . . . . 49

5.1 INTRODUCTION . . . . . . . . . . . . . . . . . 49

5.2 SPECIFIC RECOMMENDED FOLLOW-ON BENCH-SCALE TESTS . . . . . 49

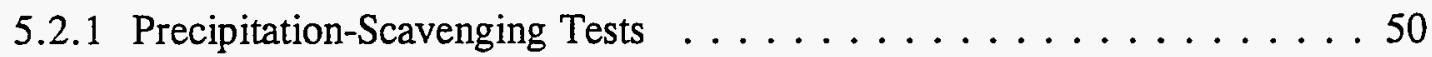

5.2 .2 Sorption Tests . . . . . . . . . . . . . . . 51

5.2.3 In-Tank Thermal Destruction of Organic Complexants . . . . . . . 51

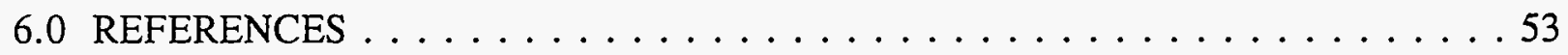

APPENDIX

A - ORGANIC COMPONENTS PRESENT IN TANK 241-SY-101 WASTE . . . 59 
WHC-SD-WM-ES-321

Revision 0

\section{LIST OF FIGURES}

1-1. Hanford Tank Waste Remediation System Strategy $\ldots \ldots \ldots \ldots$. . . . . 4

1-2. Range of Criteria for In-Tank Removal of Radionuclides

From Double-Shell Tank Waste Liquors . . . . . . . . . . . . 6

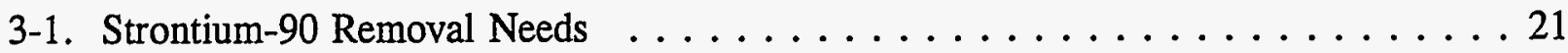

3-2. Transuranic Element Removal Needs . . . . . . . . . . . . . . 22

3-3. Technetium-99 Removal Needs $\ldots \ldots \ldots \ldots \ldots \ldots \ldots \ldots$

3-4. Cesium-137 Removal Technologies. . . . . . . . . . . . . . . . 28

3-5. Organics in Vitrification Feeds . . . . . . . . . . . 31

\section{LIST OF TABLES}

3-1. Concentration of Selected Components in Double-Shell

Tank Liquid Wastes . . . . . . . . . . . . . . . . . . 16

3-2. Estimated Weights and Volumes of Glass Resulting From Vitrification of Double-Shell Tank Supernatant Liquids. . . . . . . . . . . . . . . 19

3-3. Required Removal of Strontium-90, Technetium-99, and Transuranic Elements from Double-Shell Tank Supernatant Liquids . . . . . . . . . . . . . 20

3-4. Required Strontium-90 Decontamination Factors for Lightly-Shielded Low-Level Waste Vitrification Facility Operation . . . . . . . . . . 26

4-1. Precipitation Removal of Strontium-90 and Transuranic Elements from Complexant Concentrate Waste in Tank 241-AN-107. . . . . . . . . . . 35 
WHC-SD-WM-ES-321

Revision 0

\section{LIST OF TERMS}

$\begin{array}{ll}\text { ALARA } & \text { As low as reasonably achievable } \\ \text { CC } & \text { Complexed concentrate } \\ \text { CP } & \text { Concentrated phosphate } \\ \text { DF } & \text { Decontamination factor } \\ \text { DN } & \text { Dilute noncomplexed } \\ \text { DOE } & \text { U.S. Department of Energy } \\ \text { DSS } & \text { Double-shell slurry } \\ \text { DSSF } & \text { Double-shell slurry feed } \\ \text { DST } & \text { Double-shell tank } \\ \text { DTPA } & \text { Diethylenentriaminepentaacetate } \\ \text { EDTA } & \text { Ethylenendiaminetetraacetate } \\ \text { HEDTA } & \text { N-hydroxyethylenediaminetriacetate } \\ \text { HLW } & \text { High-level waste } \\ \text { LLW } & \text { Low-level waste } \\ \text { NCAW } & \text { Neutralized current acid waste } \\ \text { NCRW } & \text { Neutralized cladding removal waste } \\ \text { NRC } & \text { U.S. Nuclear Regulatory Commission } \\ \text { NTA } & \text { Nitrilotriacetic acid } \\ \text { PFP } & \text { Plutonium Finishing Plant } \\ \text { SST } & \text { Single-shell tank } \\ \text { TRU } & \text { Transuranic } \\ \text { TWRS } & \text { Tank Waste Remediation System }\end{array}$


WHC-SD-WM-ES-321

Revision 0

\section{IN-TANK PROCESSES FOR DESTRUCTION OF ORGANIC COMPLEXANTS AND REMOVAL OF SELECTED RADIONUCLIDES}

\subsection{INTRODUCTION}

This report establishes bases and criteria for judging the need for and the technical merit and viability of in-tank pretreatment procedures. Section 4.0 describes the data and information relative to existing technology and processes for in-tank pretreatment of doubleshell tank (DST) wastes. Section 5.0 identifies missing critical in-tank pretreatment technology for DST wastes and recommends essential follow-on bench-scale work to fill technology gaps.

\subsection{DOUBLE-SHELL TANK WASTES}

The 28 DSTs at the U.S. Department of Energy (DOE) Hanford Site currently contain $97,000 \mathrm{~m}^{3}$ of alkaline liquid waste and only about $12,000 \mathrm{~m}^{3}$ of solid waste. ${ }^{1}$ Of the DSTs, 25 are located in the 200 East area and 3 in the 200 West area; the nominal capacity of each DST is $3,800 \mathrm{~m}^{3}$.

The principal radionuclides in the DST waste are ${ }^{90} \mathrm{Sr},{ }^{99} \mathrm{Tc},{ }^{137} \mathrm{Cs}$, and transuranic (TRU) elements. Certain of the DST wastes, particularly those designated complexed concentrate (CC), contain relatively high (as much as $6 M$ carbon) concentrations of aqueous soluble organic complexing agents. TRU elements and ${ }^{90} \mathrm{Sr}$ are strongly complexed by some of the soluble organic compounds.

\subsection{OVERALL TANK WASTE REMEDIATION SYSTEM TECHNICAL STRATEGY}

The present Tank Waste Remediation System (TWRS) Technical Strategy (Wodrich 1994) for disposal of DST wastes involves the following major actions:

- As needed, and if technically feasible, perform destruction of organic complexants and concomitant or sequential removal of ${ }^{90} \mathrm{Sr}$, TRU elements, and possibly ${ }^{99} \mathrm{Tc}$.

- Retrieve waste.

\footnotetext{
${ }^{1}$ Approximately $8,200 \mathrm{~m}^{3}$ of the solids are soluble in water.
} 
WHC-SD-WM-ES-321

Revision 0

- Separate solid and liquid waste fractions.

- Separate and concentrate ${ }^{137} \mathrm{Cs}$ from the liquid fraction.

- Vitrify the liquid low-level waste (LLW) fraction, if possible, in a lightlyshielded facility. ${ }^{2}$

- Vitrify the solid high-level waste (HLW) fraction including separated ${ }^{137} \mathrm{Cs}$ and, if necessary, separated ${ }^{90} \mathrm{Sr}$, TRU elements, and ${ }^{99} \mathrm{Tc}$.

\subsection{OBJECTIVES OF THIS REPORT}

This report meets three important objectives:

1. Establish bases and criteria for judging the need for and the technical merit and viability of in-tank pretreatment procedures.

2. List and critically review data and knowledge relative to existing technology and processes and procedures for in-tank pretreatment of DST wastes.

3. Identify missing critical in-tank pretreatment technology for DST wastes and recommend bench-scale experimental work to fill technology gaps.

\subsection{BASES AND SCOPE}

The scope of this report is limited to the need and technology for in-tank pretreatment of liquid wastes currently stored in the existing 28 DSTs. It is recognized, however, that some or all of this technology also may eventually be applicable to in-tank pretreatment of waste retrieved from single-shell tanks (SSTs). Some of the water soluble SST waste may contain sufficient organic complexants and/or ${ }^{90} \mathrm{Sr},{ }^{99} \mathrm{Tc}$, and TRU elements to require in-tank pretreatment in a DST.

The need for in-tank pretreatment of each DST is addressed on a tank-by-tank basis. No credit is taken for any blending of waste liquids that may occur during plant-scale operations.

${ }^{2}$ Westinghouse Hanford Company (Alumkal 1994) recently recommended to the U.S. Department of Energy-Richland Operations Office that "the LLW vitrification facility be designed to accommodate the minimum cesium decontamination factor (DF) $(D F=100$ ) by including the necessary shielding and separate features suitable for the source term and that a lightly-shielded LLW vitrification facility not be considered for construction." 
Discussion of technology for in-tank removal of ${ }^{90} \mathrm{Sr},{ }^{99} \mathrm{Tc}$, and/or TRU elements from DST wastes, either before or after destruction of organic complexants, is restricted only to consideration of precipitation and sorption methods. Other separations technologies (e.g., solvent extraction supported liquid membrane, etc.) are not judged to be useful for in-tank application.

Only in-tank methods for oxidizing (destroying) aqueous soluble organic complexants are addressed in detail in this report. Technology that is suitable for out-of-tank destruction of organic materials is only mentioned and not discussed.

In the current TWRS Technical Strategy (Wodrich 1994), an ion exchange process operated in a shielded out-of-tank facility will be used to remove ${ }^{137} \mathrm{Cs}$ from DST alkaline liquid waste. Sorption processes useful for removal of ${ }^{90} \mathrm{Sr},{ }^{99} \mathrm{Tc}$, or TRU elements also may be suitable for operation in the radiocesium removal facility. This latter alternative is only briefly considered in this report.

\subsection{BACKGROUND INFORMATION}

\subsubsection{Double-Shell Tank Waste Remediation System Technical Strategy}

The current TWRS Technical Strategy necessarily provides only a broad overview (Figure 1-1) of the strategy and guidelines to be followed in retrieval, pretreatment, and disposal of all the wastes in tank farms located in the 200 East and 200 West areas at the Hanford Site. Important TWRS strategy considerations and/or assumptions that relate generally and specifically to DST wastes include the following:

- Retrieve wastes from all DSTs.

- Separate retrieved wastes into HLW and LLW fractions.

- Remove radionuclides from the waste stream destined to become LLW to the extent necessary to comply with the following constraints:

- The radionuclide concentrations should be less than those permitted in U.S. Nuclear Regulatory Commission (NRC) Class C commercial LLW.

- Meet the criteria for NRC "incidental waste" classification. 


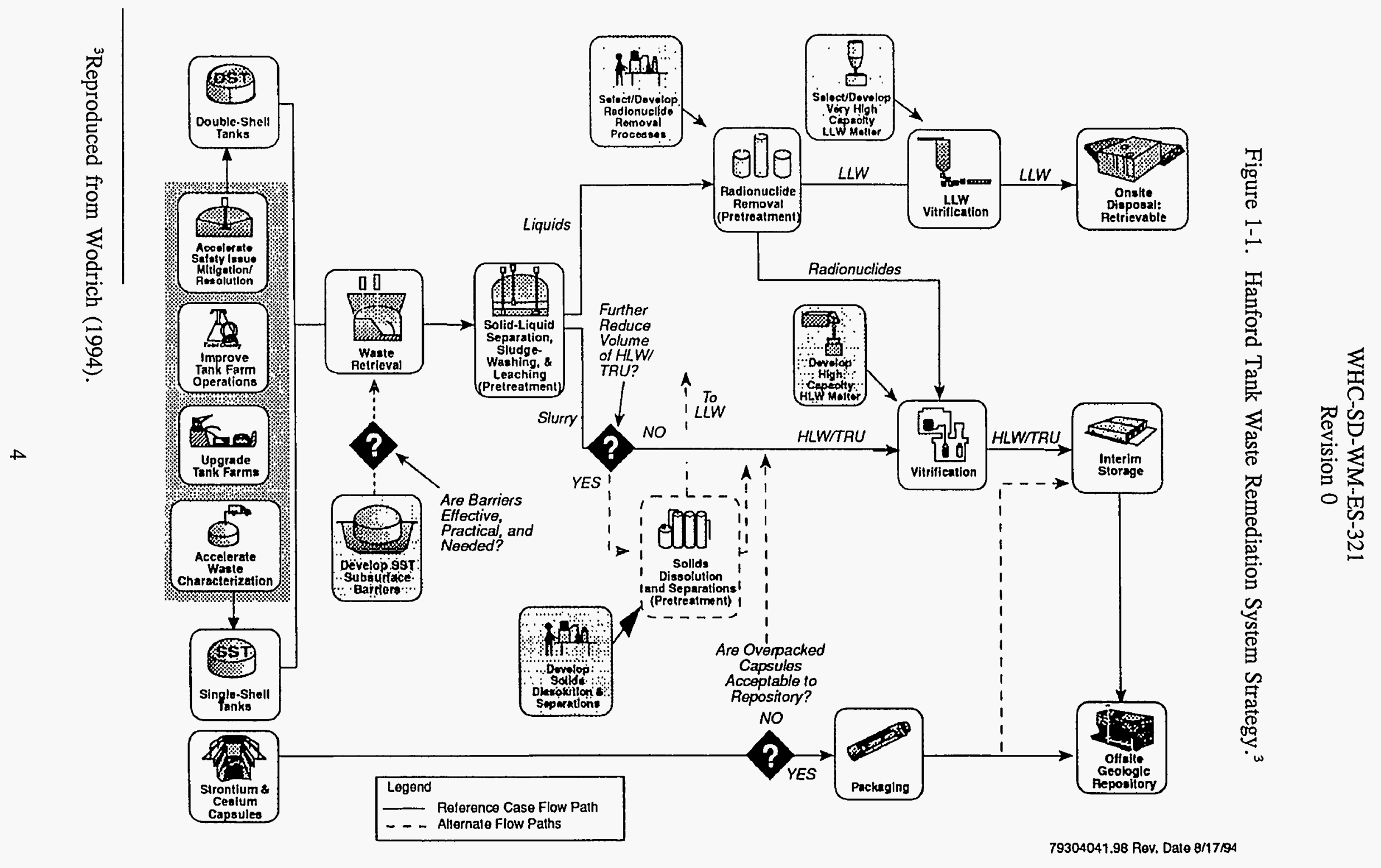




\section{WHC-SD-WM-ES-321 \\ Revision 0}

- Permit construction of a lightly-shielded LLW vitrification facility, if practical (see Section 1.2, footnote 2).

- Meet the DOE requirements for disposal of LLW, including an ALARA policy and an acceptable disposal system performance assessment.

The TWRS Technical Strategy thus establishes a hierarchy (Figure 1-2) for determining the extent to which ${ }^{137} \mathrm{Cs}$ and other radionuclides (e.g., ${ }^{90} \mathrm{Sr},{ }^{99} \mathrm{Tc}$, TRU elements, etc.) must be removed from the LLW fraction. Clearly, the LLW fraction must meet NRC Class C and incidental waste criteria with respect to radionuclide content. However, the incentive for further reduction in radionuclide content of the LLW fraction must be based upon careful evaluation and consideration of technical feasibility and costs as well as an acceptable disposal system performance assessment.

\subsubsection{Source and Composition of Complexed Concentrate Wastes}

Complexed concentrate wastes were generated in ${ }^{90} \mathrm{Sr}$ removal/recovery operations performed in the 1970's and 1980's. The liquid portion of the CC wastes contains high concentrations of various sodium salts including $\mathrm{NaNO}_{3}, \mathrm{NaNO}_{2}, \mathrm{NaAlO}_{2}, \mathrm{NaOH}$, $\mathrm{Na}_{2} \mathrm{CO}_{3}, \mathrm{Na}_{2} \mathrm{SO}_{4}$, and $\mathrm{Na}_{3} \mathrm{PO}_{4}$. Principal radionuclides present in the liquid and/or solid portions of the $\mathrm{CC}$ wastes are ${ }^{90} \mathrm{Sr},{ }^{99} \mathrm{Tc},{ }^{137} \mathrm{Cs}$, and TRU elements, mainly plutonium and americium.

Chemical flowsheets employed in ${ }^{90} \mathrm{Sr}$ recovery operations involved use of the organic complexants glycolic acid, citric acid, sodium N, N-hydroxy-ethylenediaminetriacetate (HEDTA), sodium ethylenendiaminetetracetate (EDTA), and in some cases, sodium diethylenentriaminepentaacetate (DTPA). Over time, a portion of these original organic compounds has undergone extensive chemical and radiolytic degradation. Presently, therefore, the $\mathrm{CC}$ wastes contain not only some of the original organic complexants but also a myriad of organic degradation products. Table A-1 in Appendix A lists some of the organic compounds that have been identified in the waste in Tank 241-SY-101. 


\section{Revision 0}

Figure 1-2. Range of Criteria for In-Tank Removal of Radionuclides From Double-Shell Tank Waste Liquors.

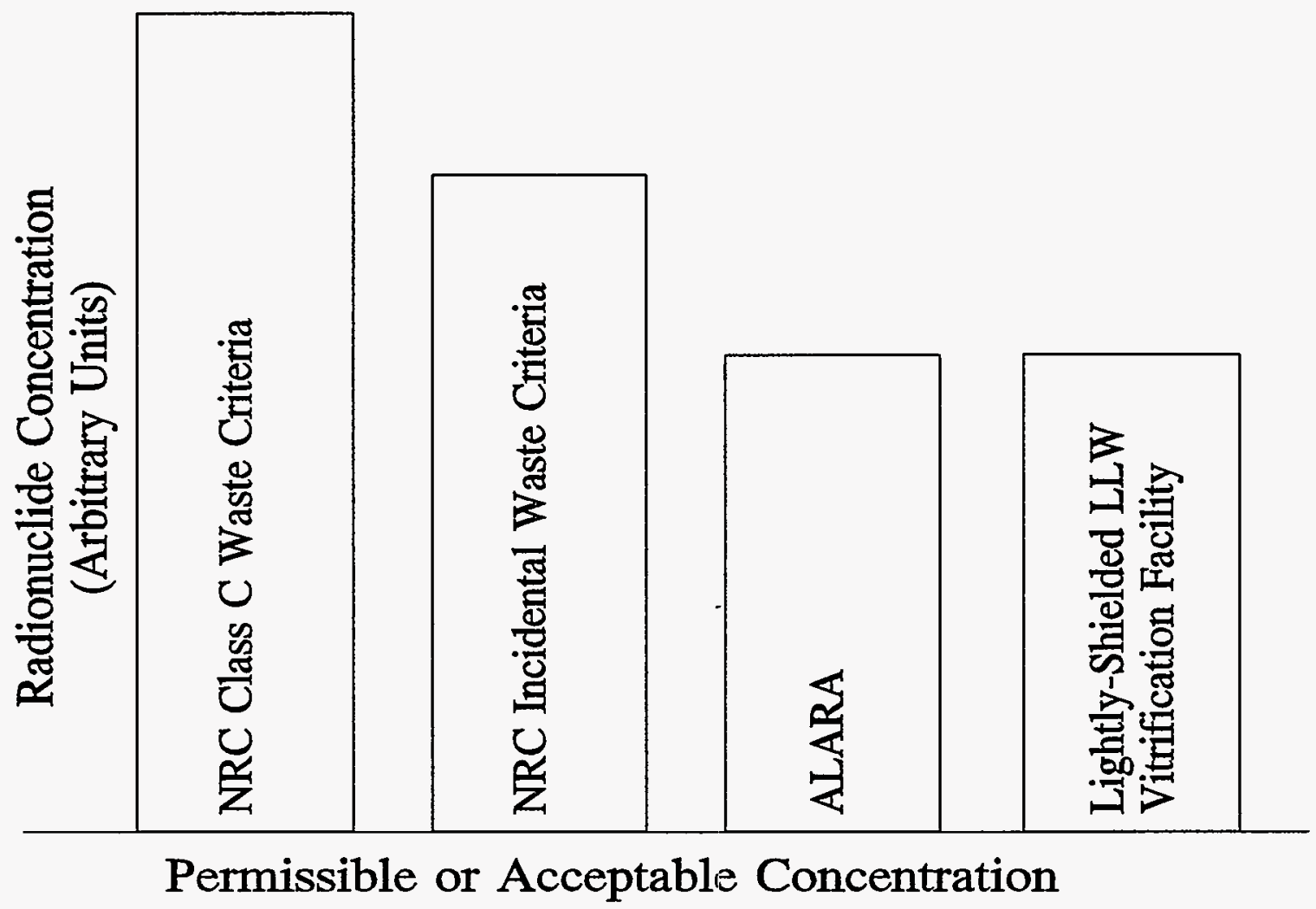
ALARA $=$ As low as reasonably achievable
LLW = Low-level waste
NRC = U.S. Nuclear Regulatory Commission 
Two important points need to be made concerning the type, concentration, and properties of aqueous-soluble organic materials in the CC waste tanks:

- For various reasons (e.g., different chemical flowsheets, different ages, different radiation fields, etc.) the suite and concentration of organic compounds present in any one of the five CC Tanks is likely different from that in the other four tanks.

- Each of the various organic complexants present in any one CC waste tank has a different propensity for forming complexes with ${ }^{90} \mathrm{Sr}$ and/or TRU elements. Thus, reflecting the first point, the extent to which TRU elements and/or ${ }^{90} \mathrm{Sr}$ are complexed by organic ligands varies from tank to tank among the CC waste tanks. 
WHC-SD-WM-ES-321

Revision 0

This page intentionally left blank. 
WHC-SD-WM-ES-321

Revision 0

\subsection{SUMMARY AND CONCLUSIONS}

A key element in the present Tank Waste Remediation System Technical Strategy for disposal of DST wastes is to determine the need and technical feasibility of in-tank destruction of organic complexants and concomitant or sequential removal of ${ }^{90} \mathrm{Sr}$, TRU elements, and possibly ${ }^{99} \mathrm{Tc}$.

This report was prepared to accomplish three important objectives:

- To establish bases and criteria for judging the need for and the technical merit and viability of in-tank pretreatment procedures.

- To list and critically review data and information relative to existing technology and processes for in-tank pretreatment of DST wastes.

- To identify missing critical in-tank pretreatment technology for DST wastes and to recommend essential follow-on bench-scale work to fill technology gaps.

Findings and conclusions stated in this report are based upon the currently available knowledge of the composition of the liquid wastes in each of the 28 DSTs based on analytical data. Composition data cited in this report for supernatants include not only those components presently in DST supernatant liquids, but also include estimates of quantities of radionuclides which could be solubilized during retrieval and sludge washing operations. Some changes in the composition database will surely occur as the result of further sampling and analysis of the DST liquid waste. It is anticipated, however, that these changes will be small and will not alter the major conclusions and findings stated in this report.

\subsection{NEEDS FOR IN-TANK PRETREATMENT PROCESSES}

\subsubsection{Removal of Strontium-90, Transuranic Elements, and Technetium-99}

Using best available composition data, the need to remove ${ }^{90} \mathrm{Sr}$, TRU elements, and ${ }^{99} \mathrm{Tc}$ from each DST waste liquor was assessed by comparing the estimated radionuclide content of vitrified waste $\left(\mathrm{d}=2.67 \mathrm{~g} / \mathrm{cm}^{3} ; 25 \mathrm{wt} \% \mathrm{Na}_{2} \mathrm{O}\right.$ ) with each of four criteria.

\subsubsection{U.S. Nuclear Regulatory Commission Class C Commercial Waste Criteria.} Neither ${ }^{90} \mathrm{Sr}$ nor ${ }^{99} \mathrm{Tc}$ have to be removed from any DST solution to obtain vitrified product containing $\leq 7,000 \mathrm{Ci} \mathrm{Sr} / \mathrm{m}^{3}$ and $\leq 3.0 \mathrm{Ci}{ }^{99} \mathrm{Tc} / \mathrm{m}^{3}$, the NRC Class $\mathrm{C}$ waste criteria. The NRC Class $\mathrm{C}$ waste criterion for TRU elements $100 \mathrm{nCi} / \mathrm{g}$. Without pretreatment, glass made from liquid waste in DSTs 241-AN-102, 241-AN-107, and 241-AY-101 (CC wastes) will exceed by factors of 1.4 to 7.6 the NRC Class $C$ waste criterion for TRU. Presently, 
WHC-SD-WM-ES-321

Revision 0

available analytical data for waste in tanks $241-\mathrm{AZ}-101$ and $241-\mathrm{AZ}-102$ indicate that the TRU element concentration in glasses made from just supernatant liquid from these tanks will be below the NRC Class $\mathrm{C}$ waste TRU element criterion of $100 \mathrm{nCi} / \mathrm{g}$. However, data also show that the TRU element concentrations of glasses made from combined supernatant and spent solid wastes will exceed the NRC Class $\mathrm{C}$ criterion by a factor of about three. The source of the TRU element contribution is from water washing the solids. Based on known actinide chemistry, it is unlikely that TRU components would be made appreciably soluble by water washing. The analyses are thus suspect, and further analysis of tank samples are recommended to verify these results.

2.1.1.2 U.S. Nuclear Regulatory Commission Incidental Waste Criteria. To be classified as Incidental Waste, the total radionuclide content of the glass produced from DSTs and SSTs for onsite disposal should not exceed 2-3 percent of the total radionuclide inventory generated from reprocessing the spent nuclear fuel. This is interpreted to be $7 \mathrm{MCi}$ total radionuclides (decay date 1999 ). If ${ }^{137} \mathrm{Cs}$ removal from the water soluble wastes is accomplished very efficiently, the Incidental Waste criterion can be met without any need to remove ${ }^{90} \mathrm{Sr}$. However, if the efficiency of the radiocesium removal process is reduced, then removal of ${ }^{90} \mathrm{Sr}$ from liquids in the five DSTs containing $\mathrm{CC}$ waste may be necessary. These latter five tanks generally contain higher amounts of ${ }^{90} \mathrm{Sr}$ than do the other DSTs.

2.1.1.3 As-Low-As-Reasonably-Achievable Principles. The exact values to which concentrations of ${ }^{90} \mathrm{Sr},{ }^{99} \mathrm{Tc}$, and TRU elements in DST supernatant liquids must be reduced to meet future agreed-to ALARA guidelines have not been specified. It is of interest that glasses made from supernatant liquids in at least 15 of the 28 DSTs will, without any in-tank pretreatment at all, contain less than $10 \mathrm{nCi} / \mathrm{g}$ of TRU elements, the NRC guideline for Class A commercial LLW. Also, the ${ }^{90} \mathrm{Sr}$ concentration in glasses made from supernatant liquid in at least 21 of the DSTs will, without any pretreatment at all, contain less than $150 \mathrm{Ci}$ ${ }^{90} \mathrm{Sr} / \mathrm{m}^{3}$, the NRC Class B commercial LLW waste limit. Guidance from ALARA principles and the TWRS Environmental Impact Statement may dictate implementation of pretreatment processes to reduce concentrations of ${ }^{90} \mathrm{Sr}$, TRU elements, and especially ${ }^{90} \mathrm{Tc}$, not only in CC waste tanks but in all DSTs.

\subsubsection{Destruction of Organic Complexants}

Complexed concentrate waste in five of the DSTs contains high concentrations of various organic carboxylates and aminopolycarboxylates and their chemical and radiolytic degradation products. TRU elements and ${ }^{90} \mathrm{Sr}$ are strongly complexed by some of the soluble organic compounds. The need to destroy some or all of the organic materials present in CC wastes was examined with respect to successful in-tank removal of ${ }^{90} \mathrm{Sr}$ and TRU elements and out-of-tank removal of ${ }^{137} \mathrm{Cs}$ and vitrification of the LLW fraction of the DST wastes.

This examination showed that: 
- Destruction of organic complexants and/or their degradation products in CC wastes is not necessary to accomplish efficient ion exchange removal of ${ }^{137} \mathrm{Cs}$.

- The need to destroy soluble organic compounds in CC wastes before their glassification depends upon the choice of vitrification equipment employed. For Joule-heated melters, organic complexants will most likely have to be destroyed. However, organic materials will likely not have to be destroyed if vitrification of the LLW is performed in combustion-type melters. In the latter case, organic compounds in the $\mathrm{CC}$ waste would provide some of the combustion energy needed to heat the molten glass.

- Destruction of organic complexants is not required to reduce by precipitation of $\mathrm{Sr}_{3}\left(\mathrm{PO}_{4}\right)_{2}$ and/or $\mathrm{Fe}_{2} \mathrm{O}_{3} \times \mathrm{H}_{2} \mathrm{O}$, the ${ }^{90} \mathrm{Sr}$ and TRU element concentration of glasses made from DST wastes, either CC or other types, to or below the NRC criteria for either Class C commercial LLW or for Incidental Waste.

- Destruction of organic complexants in CC-type DST liquid waste may be desirable or necessary to achieve some restrictive ALARA ${ }^{90} \mathrm{Sr}$ and TRU element concentration guidelines.

\subsection{STATUS OF IN-TANK PRETREATMENT TECHNOLOGY}

\subsubsection{Removal of Strontium-90 and Transuranic Elements}

Scouting tests have been performed to investigate removal of ${ }^{90} \mathrm{Sr}$ and TRU elements at 22 to $25^{\circ} \mathrm{C}$ from both actual CC waste (Tank 241-AN-107) and a composite of wastes from three non-CC type DST waste solutions. Results obtained to date show:

- ${ }^{90} \mathrm{Sr}$ is effectively removed from both CC and non-CC type DST waste solutions by addition of nonradioactive $\mathrm{Sr}\left(\mathrm{NO}_{3}\right)_{2}$ (to a concentration in the range 0.1 to $0.3 \mathrm{M}$ ) to precipitate $\mathrm{Sr}_{3}\left(\mathrm{PO}_{4}\right)_{2}$. Reflecting the effect of organic complexants, precipitation of $\mathrm{Sr}_{3}\left(\mathrm{PO}_{4}\right)_{2}$ removes ${ }^{90} \mathrm{Sr}$ from non-complexed DST waste slightly more effectively ( 99 percent) than from $\mathrm{CC}$ waste ( 95 percent).

- Precipitation of $\mathrm{Fe}_{2} \mathrm{O}_{3} \cdot \mathrm{x} \mathrm{H}_{2} \mathrm{O}$ from $\mathrm{CC}$ waste, by addition of $\mathrm{Fe}\left(\mathrm{NO}_{3}\right)_{3}$ to a concentration in the range 0.1 to $0.3 \mathrm{M}$, removes 84 to 96 percent of the ${ }^{241} \mathrm{Am}$ and 60 to 75 percent of the soluble plutonium. Americium removal is only slightly better when $\mathrm{Fe}\left(\mathrm{NO}_{3}\right)_{3}$ is added to a concentration of $0.3 \mathrm{M}$ rather than $0.1 M$.

These results, assuming they are supported by additional testing, indicate that in-tank precipitation of $\mathrm{Sr}_{3}\left(\mathrm{PO}_{4}\right)_{2}$ and $\mathrm{Fe}_{2} \mathrm{O}_{3} \cdot \mathrm{xH}_{2} \mathrm{O}$ from DST CC wastes will yield LLW easily 
meeting NRC Class C commercial waste and NRC Incidental Waste ${ }^{90} \mathrm{Sr}$ and TRU element concentration criteria. These results also indicate that, in response to possible ALARA incentives, precipitation of strontium phosphate and hydrated iron oxide from DST non-CC type wastes will significantly reduce ${ }^{90} \mathrm{Sr}$ and TRU element concentrations.

\subsubsection{Removal of Technetium-99}

No demonstrated technology exists for in-tank precipitation of ${ }^{99} \mathrm{Tc}$ from DST waste solutions. Previous work at the U.S. DOE Savannah River Site indicates that in-tank precipitation of either $\mathrm{Tc}_{2} \mathrm{~S}_{7}$ or tetraphenylphosphonium pertechnetate from DST waste may be technically feasible as a means of reducing ${ }^{95} \mathrm{Tc}$ concentrations.

\subsubsection{Destruction of Organic Complexants}

Organic complexants in CC waste form strong complexes with TRU elements and/or ${ }^{90} \mathrm{Sr}$. Destruction of certain complexants may be necessary or, at least, desirable to accomplish or enhance removal of ${ }^{90} \mathrm{Sr}$ and TRU elements from the CC wastes. Of several known methods for oxidizing organic compounds, only two -- ozonolysis and lowtemperature (e.g., $100{ }^{\circ} \mathrm{C}$ ) thermal treatment -- appear useful for in-tank application to Hanford Site DSTs. Ozonolysis suffers from the major disadvantage that all the nitrite ion, needed to prevent stress cracking corrosion, in DST solutions is quantitatively oxidized to nitrate ion before organic complexants are attacked.

Only very preliminary bench-scale tests of the effects of prolonged heating of actual DST waste solutions at $100{ }^{\circ} \mathrm{C}$ have been performed. These scouting tests clearly indicate, as expected, that the rate of gas $\left(\mathrm{H}_{2}, \mathrm{~N}_{2}, \mathrm{~N}_{2} \mathrm{O}, \mathrm{CH}_{4}\right.$, etc. $)$ generation at $100{ }^{\circ} \mathrm{C}$ is many-fold higher than it is at $65^{\circ} \mathrm{C}$, the nominal temperature in several $\mathrm{CC}$ waste tanks. Clearly, organic matter is being oxidized; however, present data are not sufficient to establish:

- Exactly which organic materials are oxidized by heating CC waste for prolonged times at $100{ }^{\circ} \mathrm{C}$.

- Whether or not the oxidized organic compounds have any effect upon removal of ${ }^{90} \mathrm{Sr}$ and TRU elements either during or after the heating period.

- How long a digestion time at $100{ }^{\circ} \mathrm{C}$ is needed to favorably influence removal of ${ }^{90} \mathrm{Sr}$ and TRU elements. 


\subsection{RECOMMENDED FOLLOW-ON EXPERIMENTAL WORK}

Few experimental data exist concerning low temperature thermal destruction of organic complexants and, to only a slightly less extent, precipitation methods which might be used on an in-tank basis for removing ${ }^{90} \mathrm{Sr},{ }^{99} \mathrm{Tc}$, and TRU elements. Lack of a sufficient amount of reliable data from tests with actual DST wastes greatly hampers evaluation and selection of feasible technology for in-tank use. To obtain a suitable data base, follow-on tests are recommended in three areas.

\subsubsection{In-Tank Precipitation Processes}

- Tests of precipitation of strontium phosphate and hydrated iron oxide for removal of ${ }^{90} \mathrm{Sr}$ and TRU elements should be performed with waste liquids from all CC Tanks and with waste solutions from a representative number (e.g., 5 to 10) of other DSTs. A primary objective of such tests should be to optimize precipitation conditions to maximize radionuclide removal efficiency and minimize reagent consumption so as to minimize the volume of vitrified HLW.

- Studies of the action of sodium titanate, both preformed and precipitated in situ, for removing ${ }^{90} \mathrm{Sr}$ and TRU elements from various classes of DST wastes.

- Tests to establish the technical viability of in-tank precipitation of $\mathrm{Tc}_{2} \mathrm{~S}_{7}$ and tetraphenylphosphonium pertechnetate from Hanford Site DST wastes as a means of reducing the ${ }^{99} \mathrm{Tc}$ concentration of such wastes. If either or both scavenging procedures are viable, additional bench-scale tests should be performed to optimize precipitation conditions for in-tank implementation.

\subsubsection{Thermal Destruction of Organic Complexants}

On-going "heat and digest" tests with CC waste from DST 241-AN-107 should be completed. The scope of these tests should be extended to include quantitative measurements of the rate at which various complexants and their degradation products are destroyed. Data should also be collected on the changes, if any, in solution concentration of ${ }^{90} \mathrm{Sr}$ and TRU elements. The behavior of radiostrontium and TRU elements when hydrated iron oxide and/or strontium phosphate are precipitated from portions of thermally treated Tank 241-AN-107 solution should be established. Finally, "heat and digest" tests also should be performed with solutions from the other three DSTs containing CC waste. 
WHC-SD-WM-ES-321

Revision 0

\subsubsection{Sorption Behavior of Strontium-90, Technetium-99, and Transuranic Elements}

The out-of-tank shielded facility for ion exchange removal of ${ }^{137} \mathrm{Cs}$ from various alkaline Hanford Site waste solutions may include in its design provision for installation of equipment for sorption removal of ${ }^{90} \mathrm{Sr}$, ${ }^{99} \mathrm{Tc}$, and TRU elements. In anticipation of this design feature, batch and column tests should be performed with DST waste solutions to establish the capacity and selectivity of crystalline sodium titanate for simultaneously sorbing ${ }^{137} \mathrm{Cs},{ }^{90} \mathrm{Sr}$, and TRU elements.

Investigators at the Argonne National Laboratory (ANL) have recently announced successful synthesis of two new organic ion exchange resins of special interest-one specific for Tc(VII) in alkaline solutions and the other capable of sorbing ${ }^{90} \mathrm{Sr}$ and TRU elements from such solutions. Progress of the ANL investigators in studying properties of these two new sorbents should be carefully monitored, and, if the ANL results warrant, tests of the new resins with actual DST solutions should be performed. 
WHC-SD-WM-ES-321

Revision 0

\subsection{IN-TANK PRETREATMENT PROCESSES NEEDS AND SELECTION CRITERIA}

\subsection{INTRODUCTION}

Proper consideration must be given to safety concerns and other issues when selecting and eventually implementing processes and technology for in-tank pretreatment of DST wastes. The selected in-tank pretreatment process operations must not present any new safety concerns and must not compromise, in any way, continued safe storage of wastes in DSTs.

The extent to which ${ }^{90} \mathrm{Sr},{ }^{99} \mathrm{Tc}$, and TRU elements need to be removed from the DST wastes by in-tank processes is obviously an important consideration. Other important process selection criteria relate to the need, if any, to destroy organic complexants to accomplish satisfactory in-tank removal of ${ }^{90} \mathrm{Sr}$ and TRU elements and out-of-tank removal of ${ }^{137} \mathrm{Cs}$ and waste vitrification operations.

\subsection{COMPOSITION OF DOUBLE-SHELL TANK LIQUID WASTES}

Table 3-1 lists concentrations of selected components in the liquid portion of DST wastes; radionuclide concentrations are decayed to December 31,1999 . Findings and conclusions stated in this report are based upon the currently available knowledge of the composition of the liquid wastes in each of the 28 DSTs based on analytical data. Composition data cited in this report for supernatants include not only those components presently in DST supernatant liquids, but also include estimates of quantities of radionuclides which could be solubilized during retrieval and sludge washing operations. Some changes in the composition database will surely occur as the result of further sampling and analysis of the DST liquid waste. It is anticipated, however, that these changes will be small and will not alter the major conclusions and findings stated in this report. Data in Table 3-1 are taken from (Shelton 1995). Data are not available for the concentrations of ${ }^{90} \mathrm{Sr},{ }^{99} \mathrm{Tc}$, and TRU elements in DSTs 241-AW-103, 241-AW-105, and 241-SY-102. Also unknown are the concentration of ${ }^{99} \mathrm{Tc}$ in liquid waste in DST 241-AW-102, the hydroxide ion concentration in liquid waste in DSTs 241-AP-104 and 241-AY-102, and the TRU element concentration in liquid waste in DST 241-AP-107.

With the exception of total organic and/or TRU element data for Tanks 241-AN-104, 241-AN-105, 241-AZ-101, and 241-AZ-102 radionuclide concentrations listed in Table 3-1 generally follow the expected pattern. Thus, the DSTs which contain CC waste also contain relatively high concentrations of ${ }^{90} \mathrm{Sr}$ and TRU elements. Tanks 241-AN-104 and 241-AN-105 also contain high concentrations of organic carbon even though they are stated to contain DSSF type waste and not CC type waste. With the exception of those in DSTs 241-AZ-101 and 241-AZ-102, wastes in all other DSTs generally contain significantly lower 
Table 3-1. Concentration of Selected Components in Double-Shell Tank Liquid Wastes.

\begin{tabular}{|c|c|c|c|c|c|c|c|}
\hline \multicolumn{8}{|c|}{ Supernatant liquid composition ${ }^{(a)}$} \\
\hline Tank & $\begin{array}{l}\text { Waste } \\
\text { Type }^{(b)}\end{array}$ & $\begin{array}{l}\mathrm{Na}^{+} \\
\mathrm{M}\end{array}$ & $\begin{array}{l}\mathrm{OH}^{-} \\
\mathrm{M}\end{array}$ & $\begin{array}{c}\text { TOC } \\
\text { g/L }\end{array}$ & $\begin{array}{c}{ }^{90} \mathrm{Sr} \\
\mu \mathrm{Ci} / \mathrm{mL}\end{array}$ & $\begin{array}{l}{ }^{99} \mathrm{Tc} \\
\mu \mathrm{Ci} / \mathrm{L}\end{array}$ & $\begin{array}{c}\text { TRU }^{(\mathrm{d})} \text { Elements } \\
\mu \mathrm{Ci} / \mathrm{L}\end{array}$ \\
\hline AN-102 & $\mathrm{CC}$ & 9.60 & 0.33 & 40.2 & 114 & 454 & 905 \\
\hline AN-107 & $\mathrm{CC}$ & 9.55 & $<1.00 \mathrm{E}-06$ & 43.9 & 87 & 438 & 461 \\
\hline $\mathrm{AY}-101$ & $\overline{\mathrm{CC}}$ & 2.56 & 0.46 & 5.95 & 122 & 146 & 43.2 \\
\hline SY-101 & $\mathrm{CC}$ & 12.4 & 1.87 & $\overline{22.7}$ & $\overline{11.1}$ & 616 & 22.6 \\
\hline SY-103 & $\overline{\mathrm{CC}}$ & 13.6 & 1.53 & 11.9 & 3.16 & 675 & 34.7 \\
\hline AN-106 & $\mathrm{CP}$ & 3.92 & 0.47 & 3.26 & 1.74 & 69.2 & 0.620 \\
\hline AP-102 & $\mathrm{CP}$ & 4.42 & 0.54 & 3.27 & 1.24 & 85.4 & 0.508 \\
\hline AN-101 & $\overline{D N}$ & 1.07 & 0.21 & 0.78 & 0.313 & 32.2 & 0.574 \\
\hline AP-101 & $\overline{\mathrm{DN}}$ & 0.19 & 0.11 & 0.024 & 0.0005 & 0.0306 & 0.403 \\
\hline AP-103 & $\overline{D N}$ & 0.23 & 0.10 & 0.11 & 0.0023 & 1.08 & 0.0204 \\
\hline AP-104 & $\overline{\mathrm{DN}}$ & 0.49 & $\overline{N A}$ & 0.12 & $2.61 \times 10^{-5}$ & 0.0507 & 0.0059 \\
\hline AP-106 & $\overline{D N}$ & 0.24 & 0.089 & 2.66 & 0.0006 & 13.3 & 0.170 \\
\hline AP-107 & $\overline{\mathrm{DN}}$ & $\overline{0.099}$ & 0.0016 & 0.052 & 0.0001 & 0.0206 & $\overline{\mathrm{NA}}$ \\
\hline AP-108 & $\overline{\mathrm{DN}}$ & 1.08 & 0.22 & 0.78 & 0.282 & 29.1 & 0.518 \\
\hline AW-102 & $\overline{D N}$ & 0.73 & 0.14 & 0.50 & 0.0330 & $\mathrm{NA}$ & 0.673 \\
\hline AW-104 & $\overline{\mathrm{DN}}$ & 1.08 & 2.19 & 0.78 & 0.352 & 36.4 & 0.648 \\
\hline AW-106 & $\overline{\mathrm{DN}}$ & 1.73 & 0.59 & 1.05 & 0.0254 & 16.7 & 0.146 \\
\hline AY-102 & $\mathrm{DN}$ & 0.155 & NA & 0.45 & 1.30 & 9.33 & 0.357 \\
\hline AN-103 & $\overline{D S S}$ & 14.5 & 5.71 & 7.31 & 11.0 & 167 & 4.50 \\
\hline AN-104 & DSSF & 12.5 & 4.25 & 57.3 & 8.52 & 181 & 14.6 \\
\hline AN-105 & DSSF & 12.0 & 3.64 & 70.0 & 2.78 & 175 & $\overline{14.6}$ \\
\hline AP-105 & $\overline{D S S F}$ & 7.24 & 3.18 & 0.18 & 0.180 & 70.0 & 0.607 \\
\hline AW-101 & DSSF & 9.91 & 5.07 & 2.51 & 0.814 & 143 & 50.4 \\
\hline$\overline{\mathrm{AZ}}-101$ & NCAW & 4.70 & 0.69 & 0.068 & 15.9 & 320 & $177^{(e)}$ \\
\hline $\mathrm{AZ}-102$ & NCAW & 2.28 & $\mathrm{NA}$ & 0.069 & 8.37 & 169 & $102^{(e)}$ \\
\hline AW-103 & NCRW & 4.12 & 0.11 & 0.77 & $\mathrm{NA}$ & NA & $\mathrm{NA}$ \\
\hline AW-105 & NCRW & 1.68 & 0.14 & 1.19 & $\mathrm{NA}$ & $\mathrm{NA}$ & $\mathrm{NA}$ \\
\hline SY-102 & PFP & 1.27 & 0.0052 & $\mathrm{NA}$ & $\mathrm{NA}$ & $\mathrm{NA}$ & $\mathrm{NA}$ \\
\hline
\end{tabular}

(a) Includes contribution of radionuclides which could be solubilized during retrieval and sludge washing operations.

(b) $\mathrm{CC}=$ Complexed concentrate

$\mathrm{CP} \quad=$ Concentrated phosphate waste

DN $=$ Dilute noncomplexed waste

DSS $=$ Double-shell slurry

DSSF $=$ Double-shell slurry feed

$\mathrm{NA}=$ Not available

(c) TOC = Total organic carbon

(d) Includes ${ }^{239} \mathrm{Pu},{ }^{240} \mathrm{Pu}$, and ${ }^{241} \mathrm{Am}$ as well as ${ }^{241} \mathrm{Am}$ produced by decay of ${ }^{241} \mathrm{Pu}$.

(e) For combination of supernatant liquid and estimated sludge washes; DF for supernatant liquid alone is $\leq 1.0$. 
WHC-SD-WM-ES-321

Revision 0

concentrations of total organic carbon, ${ }^{90} \mathrm{Sr}$, and TRU elements than do solutions in the five CC waste tanks. TRU element concentrations cited in Table 3-1 for waste in tanks 241-AZ-101 and 241-AZ-102 are for the combined supernatant liquid and estimated spent sludge washes. Some analytical data indicate that the concentration of TRU elements in supernatant liquid in tanks $241-\mathrm{AZ}-101$ and $241-\mathrm{AZ}-102$ is much less than that indicated in Table 3-1.

Technetium is generally assumed to be present in alkaline solutions as the $\mathrm{TcO}_{4}^{-}$ion. Because $\mathrm{TcO}_{4}^{-}$is so soluble in aqueous solutions, all the DST supernatant liquids contain ${ }^{99}$ Tc. However, DST waste liquids that have been concentrated (e.g., CC and DSSF solutions) generally contain high concentrations of ${ }^{99} \mathrm{Tc}$.

\subsection{REQUIRED DECONTAMINATION OF RADIONUCLIDES}

Table 3-2 provides estimates of the mass and volume of glass which will likely result from vitrification of supernatant liquid in the DSTs. This report assumes that the DST liquids shown in Table 3-1 are converted to the elemental oxides during the vitrification process. The resulting glass is formulated to contain $25 \mathrm{wt} \% \mathrm{Na}_{2} \mathrm{O}$ with all of the sodium contribution coming from the waste. Although significant blending of the waste prior to pretreatment and following pretreatment is envisioned, this report, conservatively assumes for comparison purposes, that the waste from each tank is processed/vitrified separately. The glass volume estimates in Table 3-2 assume a glass density of $2.67 \mathrm{~g} / \mathrm{cm}^{3}$.

\subsubsection{U.S. Nuclear Regulatory Commission Class C Waste Criteria}

Estimated concentrations of ${ }^{90} \mathrm{Sr},{ }^{99} \mathrm{Tc}$, and TRU elements in vitrified DST supernatant liquid are compared in Table 3-3 with NRC concentration limits (10 CFR 61) for Class C commercial LLW. For the purpose of Table 3-3, no removal of radionuclides from the DST supernatant liquids is assumed. The need for in-tank pretreatment of each DST is addressed on a tank-by-tank basis. No credit is taken for any blending of waste liquids that may occur during plant-scale operations.

3.3.1.1 Removal of Strontium-90 (Figure 3-1). For NRC Class C Commercial LLW the maximum permissible concentration of ${ }^{90} \mathrm{Sr}$ is $7,000 \mathrm{Ci} / \mathrm{m}^{3}$. Radiostrontium does not have to be removed from any DST supernatant liquid to meet this criterion. In accordance with data provided in Table $3-1$, the ${ }^{90} \mathrm{Sr}$ concentration in glasses made from waste in Tanks 241-AN-102, 241-AN-107, and 241-AY-101 (all CC waste) and in Tank 241-AY-102 will be significantly higher than that in glasses made from other DST supernatant liquids. However, even these higher ${ }^{90} \mathrm{Sr}$ concentrations are well below the NRC Class $\mathrm{C}$ limit. 
Excluding wastes in DST Tanks 241-AN-102, 241-AN-107, 241-AY-101, and 241-AY-102 the ${ }^{90} \mathrm{Sr}$ concentration in glasses made from all supernatant liquids in 21 of the DSTs will be not only below the NRC Class $C$ waste limit but also well below the NRC Class B waste limit of $150 \mathrm{Ci} / \mathrm{m}^{3}$.

3.3.1.2 Required Transuranic Element Decontarnination (Figure 3-2). For NRC Class C commercial LLW the concentration of TRU elements must not exceed $100 \mathrm{nCi} / \mathrm{g}$. Without pretreatment, this limit will be exceeded in glass made from waste in Tanks 241-AN-102, 241-AN-107, and 241-AY-101, and possibly 241-AZ-101, and 241-AZ-102. Glasses made from supernatant liquids in 15 DSTs will contain less than $10 \mathrm{nCi} / \mathrm{g}$ of TRU elements thus meeting the NRC guideline for Class A commercial LLW.

Presently, available analytical data for waste in tanks 241-AZ-101 and 241-AZ-102 indicate that the TRU element concentration in glasses made from just supernatant liquid from these tanks will be below the NRC Class C waste TRU element criterion of $100 \mathrm{nCi} / \mathrm{g}$. However, data also show that the TRU element concentrations of glasses made from combined supernatant and spent solid wastes will exceed the NRC Class C criterion by a factor of about three. The source of the TRU element contribution is from water washing the solids. Based on known actinide chemistry, it is unlikely that TRU components would be made appreciably soluble by water washing. The analyses are thus suspect, and further analysis of tank samples are recommended to verify these results.

\subsubsection{Required Technetium-99 Decontamination (Figure 3-3). For NRC Class C} commercial LLW the concentration of ${ }^{99} \mathrm{Tc}$ must not exceed $3.0 \mathrm{Ci} / \mathrm{m}^{3}$. Technetium does not have to be removed from any DST supernatant liquid to meet this criterion. However, without any removal process, the ${ }^{99} \mathrm{Tc}$ content of glasses made from liquid waste in DSTs 241-AN-102, 241-AN-107, 241-AY-101, 241-SY-101, 241-SY-103, 241-AP-106, 241-AY-102, 241-AZ-101, and 241-AZ-102 will be greater than $1.0 \mathrm{Ci} / \mathrm{m}^{3}$ of glass.

To qualify for disposal as a NRC Type A commercial waste, the waste must not contain more than $0.3 \mathrm{Ci} / \mathrm{m}^{3}$ of ${ }^{99} \mathrm{Tc}$. Glasses made from only seven of the DST supernatant liquids will meet this criterion. Further discussion of incentives to remove ${ }^{99} \mathrm{Tc}$ from all DST waste is deferred to Section 3.3.4.1. 
WHC-SD-WM-ES-321

Revision 0

Table 3-2. Estimated Weights and Volumes of Glass Resulting From Vitrification of Double-Shell Tank Supernatant Liquids."

\begin{tabular}{|c|c|c|}
\hline \multirow[b]{2}{*}{ Tank No. } & \multicolumn{2}{|c|}{ Glass } \\
\hline & Weight, Mg & Volume, $\mathrm{m}^{3}$ \\
\hline $\mathrm{AN}-102$ & 4540 & 1700 \\
\hline AN-107 & 4380 & 1640 \\
\hline AY-101 & 932 & 349 \\
\hline SY-101 & 6410 & 2400 \\
\hline$S Y-103$ & 4690 & 1760 \\
\hline AN-106 & 38.7 & 14.5 \\
\hline AP-102 & 2300 & 860 \\
\hline AN-101 & 362 & 136 \\
\hline AP-101 & 96.5 & 36.1 \\
\hline AP-103 & 122 & 45.8 \\
\hline AP-104 & 4.15 & 1.55 \\
\hline AP-106 & 127 & 47.6 \\
\hline AP-107 & 51.6 & 19.3 \\
\hline AP-108 & 571 & 214 \\
\hline AW-102 & 335 & 126 \\
\hline AW-104 & 566 & 212 \\
\hline AW-106 & 900 & 337 \\
\hline AY-102 & 51.0 & 19.1 \\
\hline AN-103 & 6520 & 2440 \\
\hline AN-104 & 6140 & 2300 \\
\hline AN-105 & 6360 & 2380 \\
\hline AP-105 & 2790 & 1040 \\
\hline AW-101 & 5340 & 2000 \\
\hline AZ-101 & 2000 & 751 \\
\hline AZ-102 & 1010 & 378 \\
\hline AW-103 & 1090 & 408 \\
\hline AW-105 & 803 & 301 \\
\hline SY-102 & 416 & 156 \\
\hline
\end{tabular}

* Glass assumed to contain $25 \mathrm{wt} \% \mathrm{Na}_{2} \mathrm{O}$ and to have a density of $2.67 \mathrm{~g} / \mathrm{cm}^{3}$. 
Table 3-3. Required Removal of Strontium-90, Technetium-99, and Transuranic Elements from Double-Shell Tank Supernatant Liquids.

\begin{tabular}{|c|c|c|c|c|c|c|}
\hline \multirow[b]{3}{*}{$\begin{array}{l}\text { Waste } \\
\text { Tank }\end{array}$} & \multicolumn{6}{|c|}{ Estimated Concentration in Vitrified Waste ${ }^{(\mathrm{a})}$} \\
\hline & \multirow[b]{2}{*}{$\begin{array}{l}{ }^{90} \mathrm{Sr} \\
\mathrm{Ci} / \mathrm{m}^{3}\end{array}$} & \multirow[b]{2}{*}{$\begin{array}{l}{ }^{99} \mathrm{Tc} \\
\mathrm{Ci} / \mathrm{m}^{3}\end{array}$} & \multirow{2}{*}{$\begin{array}{c}\text { TRU } \\
\text { Elements } \\
\text { nCi } / g\end{array}$} & \multicolumn{3}{|c|}{$\begin{array}{l}\text { Required DF to Meet } \\
\text { NRC Class C Limits }\end{array}$} \\
\hline & & & & ${ }^{90} \mathrm{Sr}$ & ${ }^{99} \mathrm{Tc}$ & $\begin{array}{c}\text { TRU } \\
\text { Elements }\end{array}$ \\
\hline AN-102 & 258 & 1.02 & 763 & None & None & 7.63 \\
\hline AN-107 & 213 & 1.07 & $\overline{422}$ & None & None & 4.22 \\
\hline AY-101 & 1030 & 1.23 & 136 & None & None & 1.36 \\
\hline SY-101 & 19.3 & 1.07 & 14.7 & None & None & None \\
\hline SY-103 & 5.01 & 1.07 & 20.6 & None & None & None \\
\hline $\mathrm{AN}-106$ & 9.52 & 0.379 & 1.27 & None & None & None \\
\hline AP-102 & 6.03 & 0.416 & 0.926 & None & None & None \\
\hline AN-101 & 6.26 & 0.645 & 4.31 & None & None & None \\
\hline AP-101 & 0.054 & 0.0034 & 16.8 & None & None & None \\
\hline AP-103 & 0.211 & 0.101 & 0.715 & None & None & None \\
\hline AP-104 & 0.0011 & 0.581 & 0.0824 & None & None & None \\
\hline AP-106 & 0.0534 & 1.20 & 5.79 & None & None & None \\
\hline $\mathrm{AP}-107$ & 0.0222 & 0.0045 & NA & None & None & $\overline{\mathrm{NA}}$ \\
\hline AP-108 & 5.61 & 0.581 & 3.87 & None & None & None \\
\hline AW-102 & 0.968 & NA & 7.43 & None & NA & None \\
\hline AW-104 & 7.03 & 0.726 & 4.84 & None & None & None \\
\hline AW-106 & 0.318 & 0.209 & 0.681 & None & None & None \\
\hline AY-102 & 194 & 1.29 & 18.5 & None & None & None \\
\hline AN-103 & 16.3 & 0.247 & 2.54 & None & None & None \\
\hline AN-104 & 14.7 & 0.313 & 9.46 & None & None & None \\
\hline $\mathrm{AN}-105$ & 5.00 & 0.315 & 9.17 & None & None & None \\
\hline AP-105 & 0.537 & 0.208 & 0.674 & None & None & None \\
\hline AW-101 & 1.77 & 0.310 & 38.5 & None & None & None \\
\hline AZ-101 & 73.0 & 1.46 & 305 & None & None & $3.05^{(c)}$ \\
\hline $\mathrm{AZ}-102$ & 78.8 & 1.59 & 359 & None & None & $3.59^{(\mathrm{c})}$ \\
\hline AW-103 & $\overline{\mathrm{NA}}$ & $\overline{\mathrm{NA}}$ & NA & $\overline{\mathrm{NA}}$ & NA & $\overline{\mathrm{NA}}$ \\
\hline AW-105 & NA & $\overline{\mathrm{NA}}$ & NA & $\mathrm{NA}$ & NA & NA \\
\hline SY-102 & $\overline{\mathrm{NA}}$ & $\overline{\mathrm{NA}}$ & $\overline{\mathrm{NA}}$ & NA & NA & NA \\
\hline
\end{tabular}

(a) Without any removal process.

$\begin{array}{ll}\text { (b) NRC Class C Waste Limit: } & { }^{90} \mathrm{Sr}=7000 \mathrm{Ci} / \mathrm{m}^{3} \\ & { }^{99} \mathrm{Tc}=3.0 \mathrm{Ci} / \mathrm{m}^{3}\end{array}$

TRU Elements $=100 \mathrm{nCi} / \mathrm{g}$

(c) For combination of supernatant liquid and estimated sludge washes; DF for supernatant liquid alone is $\leq 1.0$.

$\mathrm{NA}=$ Not available 
Figure 3-1. Strontium-90 Removal Needs.

Issue one: (A) Is removal of ${ }^{90} \mathrm{Sr}$ required to: (1) operate a lightly-shielded low-level waste vitrification facility and/or (2) to produce a glass waste form meeting prescribed waste form disposal performance assessment criteria? (B) If ${ }^{90} \mathrm{Sr}$ removal is required, what level of organic complexants can be tolerated in the feed to a strontium removal process?

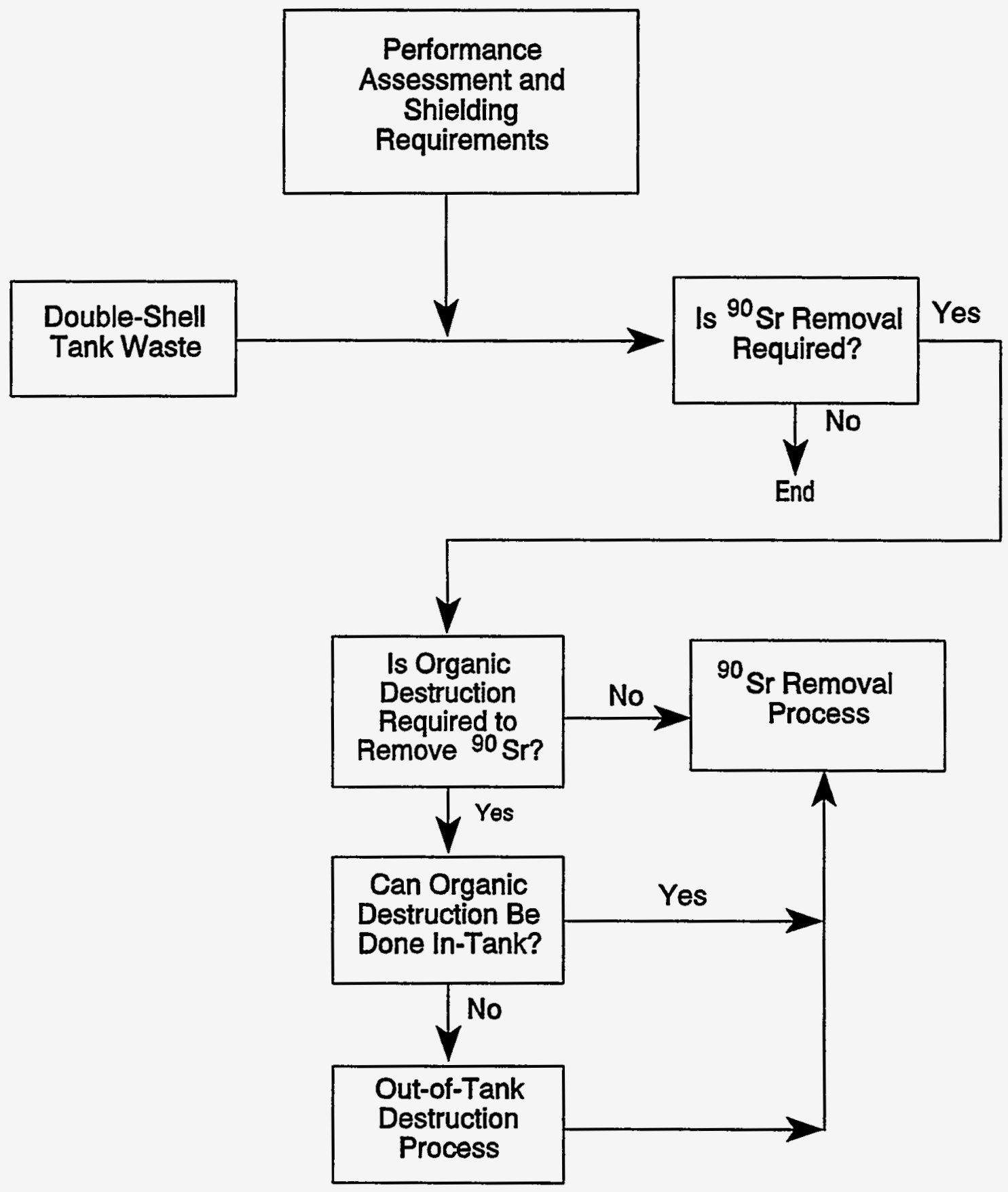


WHC-SD-WM-ES-321

Revision 0

Figure 3-2. Transuranic Element Removal Needs.

Issue two: (A) Is removal of TRU elements required to produce a glass waste form meeting regulatory criteria and/or prescribed waste form disposal performance assessment criteria?

(B) If removal of TRU elements is required, what level of organic complexants can be tolerated in the feed to a TRU element removal process?

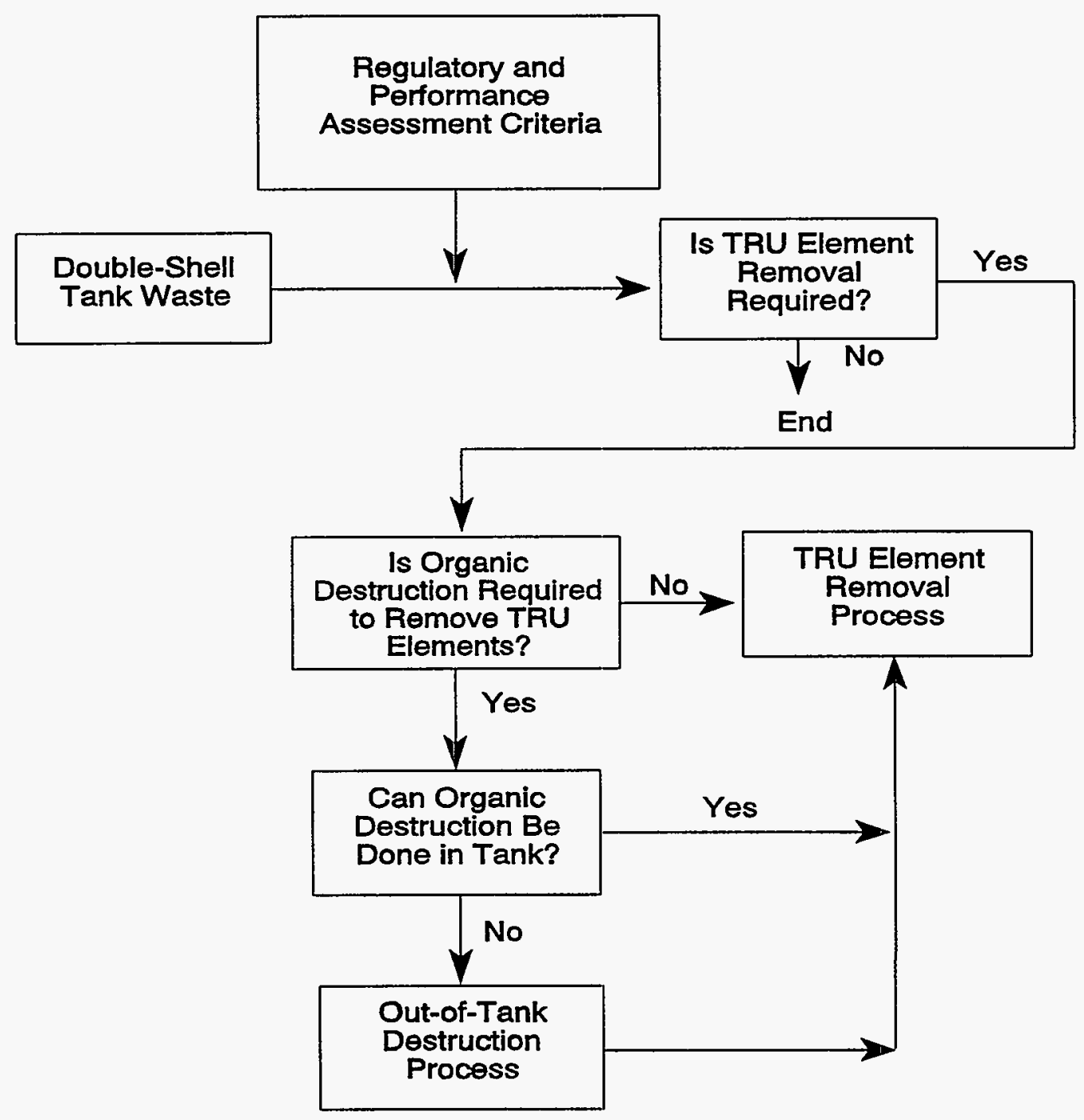

TRU $=$ Transuranic 
Figure 3-3. Technetium-99 Removal Needs.

Issue three: (A) Is removal of ${ }^{99} \mathrm{Tc}$ required to produce a glass waste form meeting regulatory criteria and/or prescribed waste form disposal performance assessment criteria? (B) If removal of ${ }^{99} \mathrm{Tc}$ is required, is available technology suitable for in-tank use?

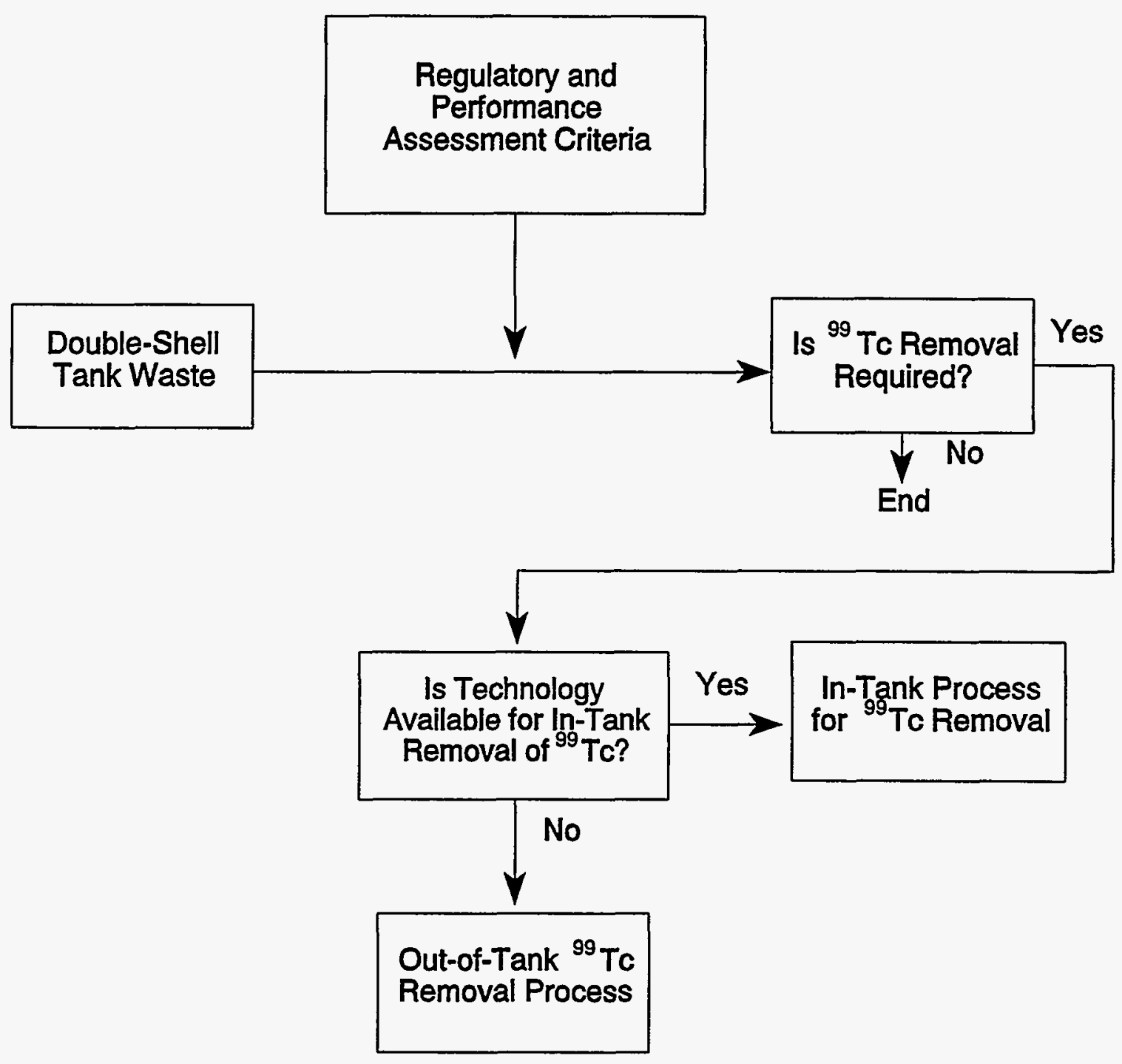


WHC-SD-WM-ES-321

Revision 0

\subsubsection{U.S. Nuclear Regulatory Commission Incidental Waste Definition and Criteria}

For several years now, discussions between DOE and NRC have been ongoing concerning the classification of the fraction of Hanford Site tank waste which is intended to be disposed of onsite, initially as a grout form and now as a glass form. The current NRC position (Bernero 1989, Bernero 1993) is that such wastes can be properly classified as Incidental Waste ${ }^{4}$ if they meet certain criteria such as the following:

- Remove key radionuclides (e.g. ${ }^{137} \mathrm{Cs},{ }^{90} \mathrm{Sr}$ ) to the maximum extent that is technically and economically practicable.

- Incorporate in a solid physical form at a concentration such that the concentrations of radionuclides do not exceed the applicable concentration limits as defined in 10 CFR Part 61.

- Manage the waste to meet safety requirements comparable to the performance objectives set out in 10 CFR Part 61.

Originally, $308 \mathrm{MCi}$ (decay date 1999) of radionuclides entered the DSTs and SSTs. Approximately $133 \mathrm{MCi}$ were removed as part of the cesium and strontium encapsulation campaign. Collectively, the water-soluble and water-insoluble (sludge) portions remaining in the DST and SST wastes contain $176 \mathrm{MCi}$ of radionuclides (decay date 1999). Of this total, about 60 percent $(110 \mathrm{MCi})$ are present in the sludge which will be vitrified and disposed of as HLW. The water-soluble portion of the SST and DST wastes contains approximately $66 \mathrm{MCi}$ of radionuclides of which about 95 percent $(63 \mathrm{MCi})$ are ${ }^{137} \mathrm{Cs}$ and only five percent are ${ }^{90} \mathrm{Sr}$. Other radionuclides (e.g., TRU elements, ${ }^{99} \mathrm{Tc}$, etc.) do not contribute significantly to the total radionuclide content of the water soluble fraction.

The current TWRS goal is to reduce the total radionuclide content of the water-soluble wastes to approximately $7 \mathrm{MCi}$ (i.e., 2-3 percent) of that originally present (decay date 1999) in the SST and DST wastes. Highly efficient ion exchange removal of ${ }^{137} \mathrm{Cs}$, without any removal of ${ }^{90} \mathrm{Sr},{ }^{99} \mathrm{Tc}$, or other radionuclides, will produce a LLW fraction meeting the first listed NRC Incidental Waste criterion. Removal of ${ }^{90} \mathrm{Sr}$ from some DST and/or SST waste solutions will be required if the cesium ion exchange process does not perform as efficiently as expected. For the DSTs, those tanks containing CC wastes will be prime candidates for implementation of ${ }^{99} \mathrm{Sr}$ removal technology since those wastes contain high concentrations of radiostrontium.

${ }^{4}$ Incidental Wastes include the miscellaneous wastes resulting from further processing of HLW to enhance the product (e.g., volume reduction) or to remove nonradioactive materials previously added to the HLW (e.g., neutralization of acidic HLW). 
WHC-SD-WM-ES-321

Revision 0

\subsubsection{Lightly Shielded Low-Level Waste Vitrification: Impacts of Feed Strontium-90 Concentration}

When initially formulated, the TWRS Technical Strategy (Section 1.4) included the potential for vitrification of the LLW fraction in a lightly-shielded facility (see section 1.2, footnote 2). Shielding requirements for such a facility are largely determined by the concentration of the gamma emitter ${ }^{137} \mathrm{Cs}$ in the melter feed. The concentration of the beta emitter ${ }^{90} \mathrm{Sr}$ in the melter feed has only a minor effect upon shielding requirements. For example, calculations described in Brown (1994) indicate per curie radiation doses from ${ }^{90} \mathrm{Sr}$ are 10 to 100 times less than from ${ }^{137} \mathrm{Cs}$. More recent analyses indicate that the ${ }^{90} \mathrm{Sr}$ concentration in the feed (at $10 \mathrm{M}$ sodium) to a lightly-shielded vitrification facility should not exceed about $90 \mathrm{uCi} / \mathrm{L}$ (Boomer et al. 1994). Below this ${ }^{90} \mathrm{Sr}$ concentration, the contribution of other radionuclides in the feed (e.g., ${ }^{155} \mathrm{Eu}$ ) to the radiation dose exceeds that from ${ }^{90} \mathrm{Sr}$.

Table 3-4 lists DFs required to reduce the ${ }^{90} \mathrm{Sr}$ concentration in DST supernatant liquid to $90 \mathrm{uCi} / \mathrm{L}$. The required DFs range from about 1 to 5,300 , the ${ }^{90} \mathrm{Sr}$ concentration in wastes in five of the DSTs is already below $90 \mathrm{uCi} / \mathrm{L}$.

\subsubsection{As-Low-As-Reasonably-Achievable Criteria: Incentives for In-Tank Removal of Technetium-99, Transuranic Elements, and Strontium-90}

Technetium-99. From an ALARA point of view it is desirable, if technically feasible, to substantially reduce the concentration of ${ }^{99} \mathrm{Tc}$ in LLW glasses made from all the DST waste liquids. Technetium- 99 has a very long half life, $t_{1 / 2}=2.13 \times 10^{5} \mathrm{y}$. The mobility of ${ }^{99} \mathrm{Tc}$, as $\mathrm{TcO}_{4}^{-}$, in the environment is well known from many performance assessments of waste disposal forms and systems. Effective removal of ${ }^{99} \mathrm{Tc}$ from the DST supernatant liquids will greatly facilitate production of glass waste forms considered satisfactory for final disposal at the Hanford Site.

Various processes (e.g., solvent extraction, supported liquid membranes, sorption, and precipitation) are known for removal of ${ }^{99} \mathrm{Tc}$ from aqueous alkaline media. Very likely, any of these processes could be operated at a cost penalty in out-of-tank facilities to remove ${ }^{99} \mathrm{Tc}$ from DST waste. The desired approach, however, is to use an in-tank ${ }^{99} \mathrm{Tc}$ precipitation or sorption removal process in conjunction with similar processes for removal of ${ }^{90} \mathrm{Sr}$ and/or TRU elements. Such a scheme would minimize both costs and time cycles. The technical issue concerns the suitability of any of the known alkaline (Section 4.2.2) sorption or precipitation methods for in-tank removal of ${ }^{99} \mathrm{Tc}$ from Hanford Site DST waste (Figure 3-3). 
WHC-SD-WM-ES-321

Revision 0

Table 3-4. Required Strontium-90 Decontamination Factors for Lightly-Shielded Low-Level Waste

Vitrification Facility Operation.

\begin{tabular}{|c|c|}
\hline Tank & Required ${ }^{90} \mathrm{Sr}$ DF \\
\hline 241-AN-102 & 1,320 \\
\hline 241-AN-107 & 1,010 \\
\hline $241-A Y-101$ & 5,300 \\
\hline 241-SY-101 & 128 \\
\hline 241-SY-103 & 25.6 \\
\hline 241-AN-106 & 49.3 \\
\hline 241-AP-102 & 31.2 \\
\hline 241-AN-101 & 32.5 \\
\hline 241-AP-101 & None \\
\hline 241-AP-103 & 1.11 \\
\hline 241-AP-104 & None \\
\hline 241-AP-106 & None \\
\hline 241-AP-107 & None \\
\hline 241-AP-108 & 29.0 \\
\hline 241-AW-102 & 5.02 \\
\hline 241-AW-104 & 36.2 \\
\hline 241-AW-106 & None \\
\hline 241-AY-102 & 963 \\
\hline 241-AN-103 & 84.3 \\
\hline 241-AN-104 & 75.8 \\
\hline 241-AN-105 & 25.7 \\
\hline 241-AP-105 & 2.77 \\
\hline 241-AW-101 & 9.12 \\
\hline 241-AZ-101 & 376 \\
\hline 241-AZ-102 & 408 \\
\hline 241-AW-103 & $\mathrm{NA}$ \\
\hline 241-AW-105 & $\mathrm{NA}$ \\
\hline 241-SY-102 & $\mathrm{NA}$ \\
\hline
\end{tabular}

$\mathrm{DF}=$ Decontamination factor

NA $=$ Not available. 
Transuranic Elements. As noted in Table 3-3, glasses made from supernatant liquids in 15 of the 28 DSTs will, without any in-tank pretreatment at all, contain less than $10 \mathrm{nCi} / \mathrm{g}$ of TRU elements, the NRC guideline for Class A commercial LLW. ALARA considerations may warrant implementation of in-tank precipitation technology to reduce actinide element concentrations, particularly uranium and neptunium. Preliminary assessments of the longterm performance of LLW glasses indicate that risks to humans from near-surface disposal of such glasses are dominated by their content of ${ }^{99} \mathrm{Tc}$, uranium, and neptunium. Environmental hazards from uranium arise from the toxicity of certain of its radioactive decay products (e.g. , ${ }^{210} \mathrm{Po}$ ), while those from ${ }^{237} \mathrm{~Np}$ result from its very long half-life $\left(\mathrm{t}_{1 / 2}=2.2 \times 10^{6} \mathrm{y}\right)$, and the mobility of $\mathrm{Np}(\mathrm{V})$, a stable oxidation state.

Strontium-90. The ${ }^{90} \mathrm{Sr}$ concentration in glasses made from supernatant liquid in 21 of the DSTs will be below the NRC Class B commercial waste limit of $150 \mathrm{Ci} / \mathrm{m}^{3}$. Glasses made from four of the DSTs will be greater than the Class B waste limit. Guidance from ALARA principles may dictate removal of ${ }^{90} \mathrm{Sr}$ from liquid wastes. ALARA principles may also provide sufficient incentive to further reduce the ${ }^{90} \mathrm{Sr}$ concentration in the former 21 DSTs. The relatively short half-life $\left(\mathrm{t}_{1 / 2}=29 \mathrm{y}\right)$ of ${ }^{90} \mathrm{Sr}$ always needs to be considered in applying ALARA principles to its removal from DST wastes. Thus, all the ${ }^{90} \mathrm{Sr}$ initially present in LLW glasses made from DST supernatant liquids will have decayed to negligible levels after only about 300 years.

\subsection{CESIUM ION EXCHANGE-EFFECT OF ORGANIC COMPLEXANTS}

The baseline TWRS Technical Strategy (Figure 1-1) involves use of an ion exchange process to remove ${ }^{137} \mathrm{Cs}$ from various alkaline liquid wastes including $\mathrm{CC}$ wastes. Concern has been expressed that high concentrations of organic complexants in CC waste could foul the resin loading and elution characteristics (Figure 3-4).

Johnson (1994) has recently summarized considerable experimental evidence which demonstrates that concern about fouling of cesium ion exchange resins by organic complexants is unfounded. For example, Kurath (1993) studied uptake of cesium from synthetic CC and Neutralized Current Acid Waste (NCAW) liquids by Duolite CS- $100^{6}$ resin (Diamond Shamrock Co.). The synthetic CC waste contained $49.5 \mathrm{~g} / \mathrm{L}$ organic carbon while no organic material was present in the synthetic NCAW solution. For both solutions, equilibrium cesium sorption characteristics were similar. No evidence for any fouling of the Duolite CS-100 resin by the organic material present in the synthetic CC waste solution was apparent.

${ }^{6}$ Duolite CS-100, ARC 359, and ES-286 are registered trademarks of Rohm and Haas, Philadelphia, Pennsylvania. 
WHC-SD-WM-ES-321

Revision 0

Figure 3-4. Cesium-137 Removal Technologies.

Issue four: What level of organic material can be tolerated in the feed to a cesium ion exchange removal process?

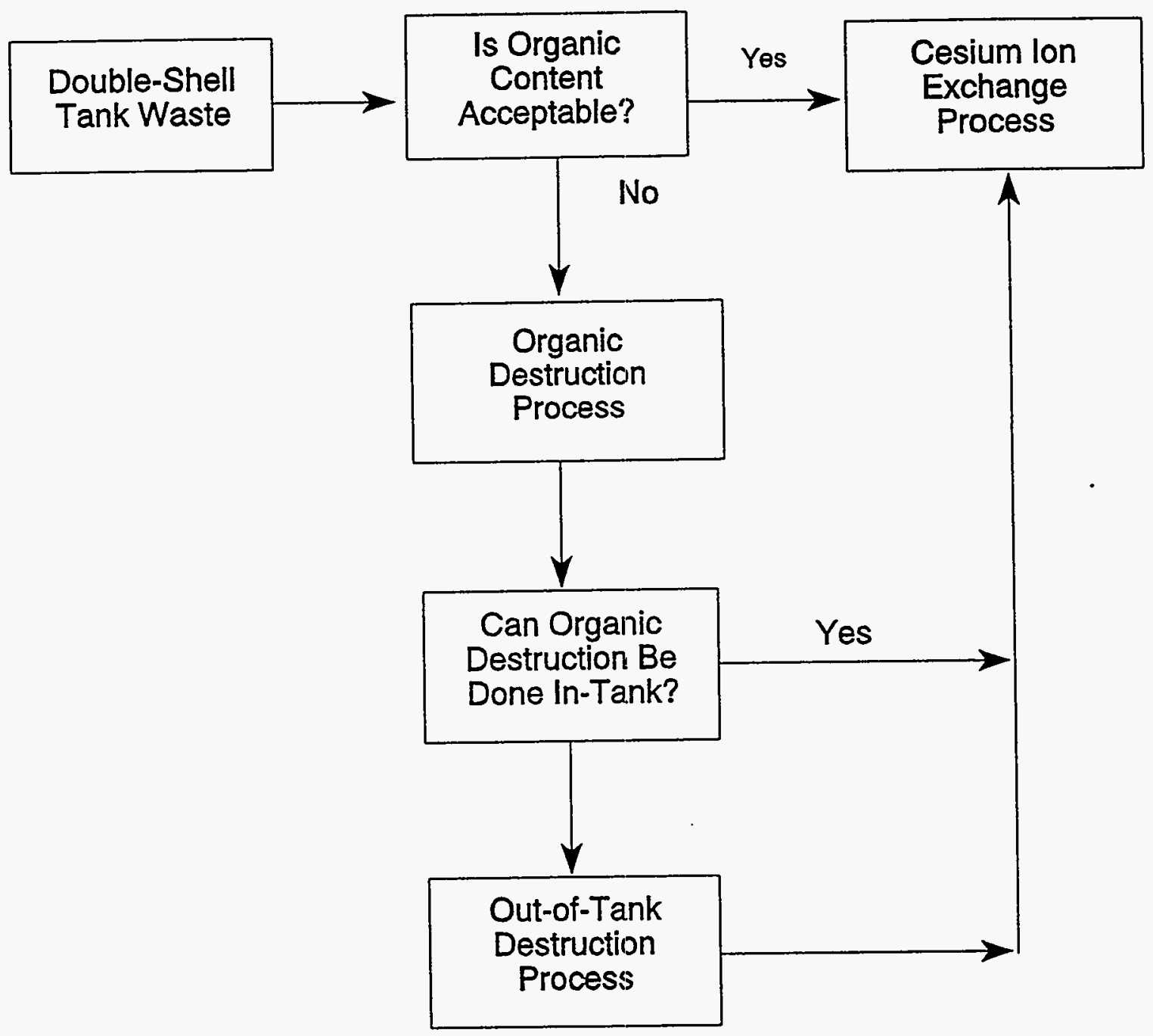


Hanford B Plant experience in the period 1967-1986 in using cation exchange resin processes for removing ${ }^{137} \mathrm{Cs}$ from aqueous feeds containing dissolved complexants was also without difficulty. From about 1970 to 1986 a phenol-based resin (Duolite ARC-359) ${ }^{7}$ was routinely used to remove ${ }^{137} \mathrm{Cs}$ from alkaline supernatant liquids from both SSTs and DSTs. Typically, HEDTA was added to the feed waste solution to complex di- and trivalent cations (e.g., $\mathrm{Fe}(\mathrm{III}), \mathrm{A} 1$ (III), $\mathrm{Ca}$ (II), etc.) to increase the cesium loading capacity of the resin and to obtain a purer cesium product. No fouling or plugging of the ion exchange bed due to the presence of large concentrations of HEDTA was ever observed. Similar excellent behavior was also noted in B Plant scale use of Duolite ES-286 resin to selectively separate ${ }^{90} \mathrm{Sr}$ from tank waste solutions to which HEDTA was added to suppress loading of trivalent cations (Johnson 1985).

In the early 1960's, immediately preceding B Plant startup, a Dowex $50^{7}$ resin bed was used at the Hanford Hot Semiworks to separate megacurie amounts of ${ }^{90} \mathrm{Sr}$ from alkaline tank wastes (Payne 1983). An organic complexant, HEDTA, was regularly added to the Dowex $50^{6}$ column feed to suppress loading of trivalent metallic ions and, to the extent possible, divalent cations such as $\mathrm{Ca}(\mathrm{II})$. Subsequently, the loaded Dowex 50 bed was washed with an $0.03 \mathrm{M}$ EDTA solution and adjusted to $\mathrm{pH} 8.4-8.8$ to isolate ${ }^{90} \mathrm{Sr}$ band from other bands containing calcium and barium. Finally, 0.1 $M$ HEDTA solution at $\mathrm{pH} 9.0$ was used to selectively elute ${ }^{90} \mathrm{Sr}$. In all these operations, no operational problems attributable to fouling or plugging of the resin bed with organic complexants were ever observed.

\subsection{WASTE VITRIFICATION PROCESSES AND FACILITIES-- EFFECTS OF ORGANIC COMPLEXANTS}

All of the organic complexants and their degradation products in CC waste contain only $\mathrm{H}, \mathrm{C}, \mathrm{O}$, and in some cases, $\mathrm{N}$ atoms. At glass melter temperatures (e.g., $\geq 1,000^{\circ} \mathrm{C}$ ) all the organic compounds will quickly decompose to yield gaseous $\mathrm{CO}_{2}, \mathrm{H}_{2} \mathrm{O}$, and $\mathrm{NO}_{\mathrm{x}}$.

Especially for Joule-heated glass melters, a long standing concern about vitrification of aqueous radioactive waste solutions containing dissolved organic materials is that the presence of easily oxidized organic compounds will adversely change the redox potential of the molten glass (Figure 3-5). The particular concern is that easily reducible materials (e.g., platinum group elements) will be converted to metals which will drastically alter the electrical properties of a Joule-heated type of glass melter. For that reason, current conservative practice in vitrification of HLW is to sharply limit the permissible total concentration of organic compounds in feed to a Joule-heated glass melter. For example, in

${ }^{7}$ Duolite CS-100, ARC 359, and ES-286 are registered trademarks of Rohm and Haas, Philadelphia, Pennsylvania

Dowex 50 is a trademark of Dow Chemical Company. 
WHC-SD-WM-ES-321

Revision 0

the proposed Hanford Waste Vitrification Plant for conversion of high-level waste to a borosilicate-type glass the specification for the permissible concentration of organic material in the melter feed was $0.11 \mathrm{~g}$ carbon per $\mathrm{g}$ of inorganic feed oxides. For vitrification of DST supernatant liquids, the dominant inorganic feed oxide is $\mathrm{Na}_{2} \mathrm{O}$. Data in Table 3.1 show that, without destruction of organic complexants, the ratio of organic carbon to $\mathrm{Na}_{2} \mathrm{O}$ will exceed 0.11 for wastes in DSTs 241-AN-102, 241-AN-104, 241-AN-105, 241-AN-107, and 241-AY-101.

The present TWRS Technical Strategy does not specify either the type of glass to be made from LLW feeds or the melter equipment to be used to vitrify the LLW. However, considering the sodium content of the LLW melter feeds, it is likely that a glass formulation that accommodates high levels of sodium (e.g., soda lime type glass) may be selected. Also, in order to avoid any complications imposed by the presence of organic materials in the radioactive feed to the vitrification process, it is desirable to choose melter equipment which does not rely on Joule-heating to obtain molten glass. One possible candidate is a combustion-heated melter. In such a melter, organic materials in the feed would simply provide part of the fuel to be combusted and would not compromise melter operation or the quality of the final glass. 
WHC-SD-WM-ES-321

Revision 0

Figure 3-5. Organics in Vitrification Feeds.

Issue five: What level of organic material can be tolerated in the feed to high-level and lowlevel vitrification facilities?

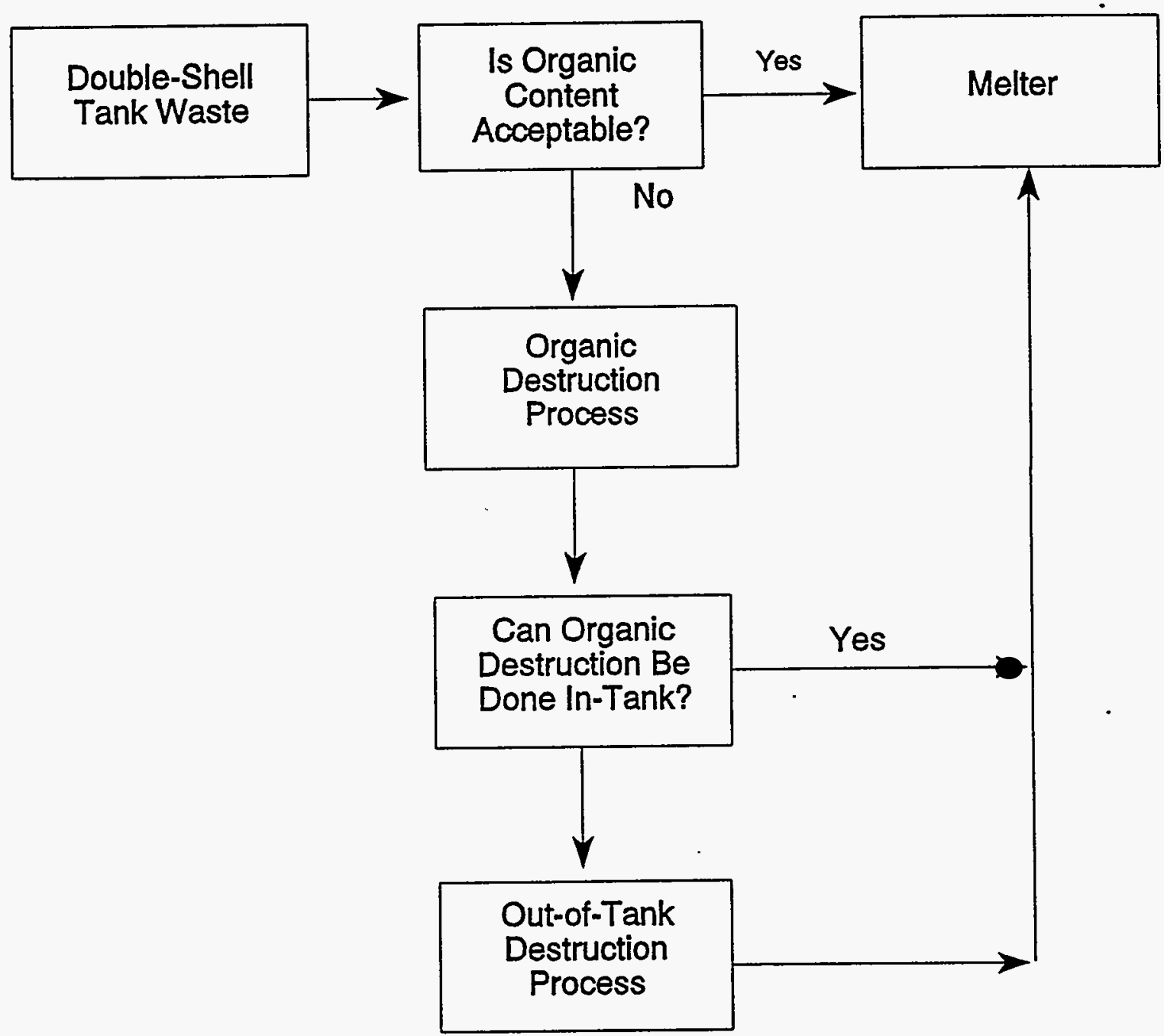




\section{WHC-SD-WM-ES-321}

Revision 0

This page intentionally left blank. 


\subsection{REVIEW AND EVALUATION OF EXISTING EXPERIMENTAL DATA FOR IN-TANK PRETREATMENT OF DOUBLE-SHELL TANK WASTES}

\subsection{INTRODUCTION}

Precipitation methods potentially useful for in-tank removal of ${ }^{90} \mathrm{Sr}$, TRU elements, and ${ }^{99} \mathrm{Tc}$ from DST waste solutions are discussed in the first part of Section 4.0. For removal of radiostrontium and/or TRU elements such methods include precipitation of hydrated iron oxide $\left(\mathrm{Fe}_{2} \mathrm{O}_{3}, \mathrm{x} \mathrm{H}_{2} \mathrm{O}\right)$, nonradioactive strontium phosphate $\left(\mathrm{Sr}_{3}\left(\mathrm{PO}_{4}\right)_{2}\right)$, and sodium titanate $\left[\mathrm{Na}\left(\mathrm{Ti}_{2} \mathrm{O}_{5} \mathrm{H}\right)\right]$. In-tank removal of ${ }^{99} \mathrm{Tc}$ by precipitation either as $\mathrm{Tc}_{2} \mathrm{~S}_{7}$ or tetraphenylphosphonium pertechnetate is discussed. In all cases existing data obtained.with simulated and actual wastes are summarized and used to make preliminary judgements concerning applicability of particular precipitation schemes to in-tank removal of selected radionuclides.

To meet some decontamination criteria (e.g., ALARA guidance) destruction of some or all of the organic complexants in CC wastes may be necessary to accomplish required removal of ${ }^{90} \mathrm{Sr}$ and/or TRU elements. Of several known methods for destroying organic complexants in DST wastes, only two--thermal treatment at approximately $100^{\circ} \mathrm{C}$ and ozonation--are considered potentially useful for in-tank application. Relevant experimental data for these two methods obtained with both simulated and actual wastes are discussed in terms of the perceived advantages and disadvantages of each technology. The current paucity of data for low temperature $\left(\leq 100^{\circ} \mathrm{C}\right)$ thermal destruction of organic complexants is a serious obstacle to judging the merits of this process for in-tank application.

Certain organic and/or inorganic sorbents may be useful for removal of ${ }^{90} \mathrm{Sr}$, TRU elements, and ${ }^{99} \mathrm{Tc}$ in the same out-of-tank shielded facility used for removal of ${ }^{137} \mathrm{Cs}$ from alkaline waste solution. Candidate sorbents and their application are briefly discussed.

\subsection{PRECIPITATION REMOVAL OF STRONTIUM-90 AND TRANSURANIC ELEMENTS}

\subsubsection{By Metal Hydroxides and Phosphates}

Both Herting (1993, 1994a, 1994b) and Washington (1990) have performed experiments with actual DST wastes to investigate effects of changes in waste hydroxide ion content upon precipitation of TRU elements and ${ }^{90} \mathrm{Sr}$. Herting's work has also included studies of the effects of addition of various metal nitrates (e.g., $\mathrm{Sr}(\mathrm{II}), \mathrm{Ni}(\mathrm{II}), \mathrm{Fe}(\mathrm{III})$, etc.) to DST waste solutions to improve precipitation of TRU elements and ${ }^{90} \mathrm{Sr}$. 
WHC-SD-WM-ES-321

Revision 0

Relevant details and results of the Washington and Herting experiments are summarized and evaluated in the remaining text in this section. It should be kept in mind that these experiments comprise all those done to date relative to in-tank precipitation of TRU elements and ${ }^{90} \mathrm{Sr}$ from actual DST wastes.

\subsubsection{Tests With Actual Complexed Concentrate Wastes. Washington (1990)} conducted several tests with actual Tank 241-AN-107 (CC waste) waste to study effects of increasing the free hydroxide ion concentration from $<0.02 M$ to a value in the range 0.48 to $0.65 \mathrm{M}$. After hydroxide ion concentration adjustment, Washington let portions of solution stand (a) 24 hours at room temperature, (b) 30 days at room temperature, and (c) 42 hours at $100{ }^{\circ} \mathrm{C}$. In the latter case, Washington observed about a two-fold decrease in the concentration of TRU elements, presumably as a result of precipitation of their hydroxides. Washington reported that he also observed a slight decrease in the TRU element concentration of the solutions which were allowed to stand at room temperature, but upon close inspection Washington's data do not support the latter observation. The behavior of ${ }^{90} \mathrm{Sr}$ in these experiments was not studied.

Three years after Washington's work, Herting (1993) further investigated the effects of adding $\mathrm{NaOH}$ to Tank 241-AN-107 supernatant liquid. Herting adjusted portions of the Tank 241-AN-107 waste liquor to free hydroxide ion concentrations in the range 0.26 to $1.47 \mathrm{M}$ and then let them stand 24 hours at room temperature. No precipitates were observed to form in any test, and no changes in either TRU element or ${ }^{90} \mathrm{Sr}$ concentrations were noted.

Herting also performed two tests to study the action of $\mathrm{Fe}_{2} \mathrm{O}_{3} \cdot \mathrm{xH}_{2} \mathrm{O}$ and $\mathrm{Sr}_{3}\left(\mathrm{PO}_{4}\right)_{2}$ in precipitating (scavenging) TRU elements. In these latter tests, portions of waste adjusted to about $1.4 \mathrm{M}$ free hydroxide ion were made either $0.01 \mathrm{MFe}\left(\mathrm{NO}_{3}\right)_{3}$ or $\mathrm{Sr}\left(\mathrm{NO}_{3}\right)_{2}$ and stirred 24 hours at room temperature. In both tests, Herting noted a two- to three-fold decrease in the TRU element concentration but no change in ${ }^{90} \mathrm{Sr}$ concentration. Herting's latter results were obtained without any attempt to destroy organic complexants and with only minimal addition of precipitating agents. Even under these relatively unfavorable conditions, two- to three-fold decreases in TRU element concentration occurred.

Herting (1994a, 1994b) extended his tests with waste from Tank 241-AN-107 to study effects of adding 10 - and 30 -fold greater amounts of precipitating agents. In particular, Herting performed precipitation tests at 22 to $25^{\circ} \mathrm{C}$, with portions of Tank 241-AN-107 liquid waste previously adjusted to either 1.5 or $3.0 \mathrm{M} \mathrm{NaOH}$. Appropriate amounts of stock $1.1 \mathrm{M} \mathrm{Fe}\left(\mathrm{NO}_{3}\right)_{3}$ and/or $1.1 \mathrm{M} \mathrm{Sr}\left(\mathrm{NO}_{3}\right)_{2}$ solution were added to adjust the waste solution to either $0.1 M \mathrm{Fe}$ (III or $\mathrm{Sr}$ (II) or $0.3 \mathrm{MFe}$ (III). . In one test, the adjusted waste solution was made $0.1 \mathrm{M} \mathrm{Fe}(\mathrm{III}), 0.1 \mathrm{M} \mathrm{Sr}$ (II) and also $0.1 \mathrm{MPO}_{4}{ }^{3-}$ by addition of solid $\mathrm{Na}_{3} \mathrm{PO}_{4} \cdot 12 \mathrm{H}_{2} \mathrm{O}$. After addition of precipitating agents, test solutions were agitated for five days before centrifugation to separate solid and liquid phases. Results of these tests are summarized in Table 4-1. The significance of the Washington and Herting results to in-tank removal of radiostrontium and TRU elements from DST wastes is discussed in Section 4.2.1.3. 
WHC-SD-WM-ES-321

Revision 0

Table 4-1. Precipitation Removal of Strontium-90 and Transuranic Elements from Complexant Concentrate Waste in Tank 241-AN-107.

A. Waste adjusted to $1.5 \mathrm{M} \mathrm{NaOH}$.

\begin{tabular}{|l|c|c|c|c|c|c|c|}
\hline \multicolumn{2}{|c|}{$\begin{array}{c}\text { Precipitation } \\
\text { conditions }\end{array}$} & \multicolumn{2}{c|}{ Residual radionuclide concentration ${ }^{(2)}$} & \multicolumn{3}{c|}{ Percent removed } \\
\hline Reagent & $\begin{array}{c}\text { Final } \\
\text { Conc. } \mathrm{M}\end{array}$ & $\begin{array}{c}{ }^{90} \mathrm{Sr} \\
\mu \mathrm{Ci} / \mathrm{mL}\end{array}$ & $\begin{array}{c}\mathrm{Pu} \\
\mu \mathrm{Ci} / \mathrm{mL}\end{array}$ & $\begin{array}{c}{ }^{241} \mathrm{Am} \\
\mu \mathrm{Ci} / \mathrm{mL}\end{array}$ & ${ }^{90} \mathrm{Sr}$ & ${ }^{241} \mathrm{Am}$ \\
\hline $\mathrm{None}^{(\mathrm{b})}$ & & 79.4 & 0.025 & 0.48 & 15 & 26 & 24 \\
\hline $\mathrm{Fe}\left(\mathrm{NO}_{3}\right)_{3}$ & 0.1 & 42.6 & 0.015 & 0.10 & 54 & 56 & 84 \\
\hline $\mathrm{Fe}\left(\mathrm{NO}_{3}\right)_{3}$ & 0.3 & 30.2 & 0.013 & 0.075 & 68 & 62 & 88 \\
\hline $\mathrm{Sr}\left(\mathrm{NO}_{3}\right)_{2}$ & 0.1 & 4.3 & 0.030 & 0.36 & 95 & 12 & 43 \\
\hline $\mathrm{Fe} / \mathrm{Sr}_{\mathrm{PO}}{ }_{4}^{(\mathrm{c})}$ & 0.1 & 5.7 & 0.015 & 0.092 & 94 & 56 & 85 \\
\hline $\mathrm{Fe} / \mathrm{Fe}^{(\mathrm{d})}$ & 0.1 & 20.5 & 0.011 & 0.028 & 7.8 & 68 & 96 \\
\hline
\end{tabular}

(a) Normalized to undiluted Tank 241-AN-107 waste

(b) Effect of adjusting waste to $1.5 \mathrm{M} \mathrm{NaOH}$

(c) Test solution made $0.1 \mathrm{MFe}$ (III), $0.1 \mathrm{M} \mathrm{Sr}$ (II), and $0.1 \mathrm{M} \mathrm{PO}_{4}{ }^{-3}$.

(d) Double scavenging: Supernatant liquid from first precipitation step adjusted to $0.1 \mathrm{M}$

$\mathrm{Fe}\left(\mathrm{NO}_{3}\right)_{3}$ and agitated 5 days at 23 to $25^{\circ} \mathrm{C}$.

B. Waste adjusted to $3.0 \mathrm{M} \mathrm{NaOH}$

\begin{tabular}{|c|c|c|c|c|c|c|c|}
\hline \multicolumn{2}{|c|}{$\begin{array}{l}\text { Precipitation } \\
\text { conditions }\end{array}$} & \multicolumn{3}{|c|}{ Residual radionuclide concentration ${ }^{(2)}$} & \multicolumn{3}{|c|}{ Percent removed } \\
\hline Reagent & $\begin{array}{c}\text { Final Conc. } \\
\mathrm{M}\end{array}$ & $\begin{array}{c}{ }^{90} \mathrm{Sr} \\
\mu \mathrm{Ci} / \mathrm{mL} \\
\end{array}$ & $\underset{\mu \mathrm{Ci} / \mathrm{mL}}{\mathrm{Pu}}$ & $\begin{array}{l}{ }_{\mu}^{241} \mathrm{Am} \\
\mathrm{Ci} / \mathrm{mL}\end{array}$ & ${ }^{90} \mathrm{~S}_{\Gamma}$ & $\mathrm{Pu}$ & ${ }^{241} \mathrm{Am}$ \\
\hline None $e^{(b)}$ & & 61.9 & 0.025 & 0.16 & 33 & 26 & 75 \\
\hline $\mathrm{Fe}\left(\mathrm{NO}_{3}\right)_{3}$ & 0.1 & 46.9 & & 0.026 & 50 & & 96 \\
\hline $\mathrm{Fe}\left(\mathrm{NO}_{3}\right)_{3}$ & 0.3 & 19.5 & 0.0084 & 0.032 & 79 & 75 & 95 \\
\hline $\mathrm{Sr}\left(\mathrm{NO}_{3}\right)_{2}$ & 0.1 & 5.0 & 0.027 & 0.35 & 95 & 21 & 44 \\
\hline $\mathrm{Fe} / \mathrm{Sr} / \mathrm{PO}_{4}{ }^{(\mathrm{c})}$ & 0.1 & 4.6 & 0.012 & 0.058 & 95 & 65 & 91 \\
\hline $\mathrm{Fe} / \mathrm{Fe}^{(\mathrm{d})}$ & 0.1 & 15.2 & 0.012 & 0.017 & 84 & 65 & 97 \\
\hline
\end{tabular}

(a) Normalized to undiluted Tank 241-AN-107 waste

(b) Effect of adjusting waste to $3.0 \mathrm{M} \mathrm{NaOH}$

(c) Test solution made $0.1 \mathrm{MFe}(\mathrm{II}), 0.1 \mathrm{M} \mathrm{Sr}(\mathrm{II})$, and $0.1 \mathrm{M} \mathrm{PO}_{4}{ }^{3}$.

(d) Double scavenging: Supernatant liquid from first precipitation step adjusted to $0.1 \mathrm{M}$ $\mathrm{Fe}\left(\mathrm{NO}_{3}\right)_{3}$ and agitated 5 days at 23 to $25^{\circ} \mathrm{C}$. 
WHC-SD-WM-ES-321

Revision 0

\begin{abstract}
4.2.1.2 Tests with Actual Double-Shell Slurry Feed, Dilute Noncomplexed, and Concentrated Phosphate Wastes. Herting (1994b) has recently completed important precipitation tests with a composite solution prepared by mixing waste solutions from Tank 241-AW-101 (70 vol\%), Tank 241-AP-106 (20 vol\%), and Tank 241-AP-102 (10 vol\%). Wastes in these tanks are classified as DSSF, DN, and CP waste, respectively (see Table 3-1).
\end{abstract}

The composite waste solution contained about $0.3 \mathrm{uCi} / \mathrm{mL}$ of ${ }^{90} \mathrm{Sr}$ and $0.012 \mathrm{uCi} / \mathrm{mL}$ TRU elements. Its free hydroxide ion concentration was $4.4 \mathrm{M}$, and it contained $4.2 \mathrm{~g} / \mathrm{L}$ organic carbon. Compared to solutions in the CC waste tanks (Table 3-1), the composite waste solution contained 10 - to 1,000 -fold less ${ }^{90} \mathrm{Sr}$ and 50- to $5.5 \mathrm{E}-04$ times less TRU elements. The total organic carbon concentration of the composite waste solution was about 100-fold lower than that in CC wastes in Tank 241-AN-102 and Tank 241-AN-107, but approximately equal to that in CC wastes in Tanks 241-AY-101 and 241-SY-101.

In his tests, Herting added $1 \mathrm{M}$ solutions of various precipitants to filtered aliquots of the composite DSSF waste. In all cases, the resulting solutions were stirred 24 hours at room temperature, centrifuged for 20 minutes, and then analyzed. Also, in all cases waste solutions were made 0.1 in precipitating agent.

Precipitants tested included $\mathrm{Ca}(\mathrm{II}), \mathrm{Mn}(\mathrm{II}), \mathrm{Ni}(\mathrm{II}), \mathrm{Sr}(\mathrm{II}), \mathrm{CO}_{2}{ }^{3-}, \mathrm{SO}_{4}{ }^{2-}$, and $\mathrm{PO}_{4}{ }^{3-}$. Metals were added as nitrate solutions and anions as solutions of their sodium salts. Precipitates formed immediately upon addition of solutions of $\mathrm{Ca}\left(\mathrm{NO}_{3}\right)_{2}, \mathrm{Mn}\left(\mathrm{NO}_{3}\right)_{2}$, $\mathrm{Ni}\left(\mathrm{NO}_{3}\right)_{2}$, and $\mathrm{Sr}\left(\mathrm{NO}_{3}\right)_{2}$ to the composite waste. A precipitate formed slowly when $\mathrm{Na}_{3}\left(\mathrm{PO}_{4}\right)_{2}$ solution was added to the composite waste. Precipitates did not form upon addition of either $\mathrm{Na}_{2} \mathrm{CO}_{3}$ or $\mathrm{Na}_{2} \mathrm{SO}_{4}$ solution. Addition of one volume of $1 M \mathrm{Sr}\left(\mathrm{NO}_{3}\right)_{2}$ solution to 10 volumes of composite waste removed 99.4 percent of the ${ }^{90} \mathrm{Sr}$ $\left({ }^{90} \mathrm{Sr} \mathrm{DF}=170\right)$. About 98.5 percent $\left({ }^{90} \mathrm{Sr} \mathrm{DF}=120\right)$ of the ${ }^{90} \mathrm{Sr}$ precipitated when $\mathrm{Ni}\left(\mathrm{NO}_{3}\right)_{2}$ was substituted for $\mathrm{Sr}\left(\mathrm{NO}_{3}\right)_{2}$. Of the other precipitating agents tested, ${ }^{90} \mathrm{Sr} \mathrm{DFs}$ of about 7 were obtained with $\mathrm{Mn}(\mathrm{II})$ and $\mathrm{Ca}(\mathrm{II})$. None of the other reagents were effective in removing radiostrontium. The concentrations of ${ }^{157} \mathrm{Cs}$ and TRU elements in the composite waste solution were not affected by addition of any of the precipitating agents.

The significance of the Herting results to in-tank removal of ${ }^{90} \mathrm{Sr}$ and/or TRU elements from DST waste liquors is discussed in Section 4.2.1.3.

4.2.1.3 Significance of Hydroxide and Phosphate Precipitation Tests. Several important findings are evident from Herting's scavenging experiments with both $\mathrm{CC}$ and a composite of non-CC waste:

- Increase in the hydroxide ion concentration of the CC waste in Tank 241-AN-107 from $<0.05 \mathrm{M}$ to 1.5 or $3.0 \mathrm{M}$ results in precipitation of 15 to 33 percent of the ${ }^{90} \mathrm{Sr}, 26$ percent of the plutonium, and 24 to 75 percent of the ${ }^{241} \mathrm{Am}$. More ${ }^{90} \mathrm{Sr}$ and ${ }^{241} \mathrm{Am}$ precipitated at the higher bydroxide concentration. This latter 
behavior is in accord with Washington's (1990) preliminary observations and also with Ryan's predictions (Ryan 1992).

- ${ }^{90} \mathrm{Sr}$ is effectively removed from both CC and non-CC DST waste solutions by addition of nonradioactive $\mathrm{Sr}\left(\mathrm{NO}_{3}\right)_{2}$ to precipitate $\mathrm{Sr}_{3}\left(\mathrm{PO}_{4}\right)_{2}$. Reflecting the effects of organic complexants, precipitation of $0.1 M \mathrm{Sr}_{3}\left(\mathrm{PO}_{4}\right)_{2}$ removes ${ }^{90} \mathrm{Sr}$ from non-complexed waste slightly more efficiently ( 99 percent) than from CC waste (95 percent).

- TRU elements are not removed from DST waste solutions to any significant extent by precipitation of $\mathrm{Sr}_{3}\left(\mathrm{PO}_{4}\right)_{2}$.

- Precipitation of $\mathrm{Fe}_{2} \mathrm{O}_{3} . \mathrm{x} \mathrm{H}_{2} \mathrm{O}$ from $\mathrm{CC}$ waste (Tank 241-AN-107) removes 84 to 96 percent of the ${ }^{241} \mathrm{Am}$. Americium removal is only slightly better when $\mathrm{Fe}\left(\mathrm{NO}_{3}\right)_{3}$ is added to a concentration of $0.3 \mathrm{M}$ rather than $0.1 \mathrm{M}$.

- Precipitation of $\mathrm{Fe}_{2} \mathrm{O}_{3} . \times \mathrm{H}_{2} \mathrm{O}$ from CC waste also removes 60 to 75 percent of the soluble plutonium. Inferior removal of plutonium compared to that for americium by addition of $\mathrm{Fe}\left(\mathrm{NO}_{3}\right)_{3}$ to the $\mathrm{CC}$ waste may reflect stronger complexing of $\mathrm{Pu}(\mathrm{IV})$ over that of $\mathrm{Am}(\mathrm{III})$.

These observations, assuming they are supported by additional tests with other $\mathrm{CC}$ and non-CC wastes (Section 5.0), indicate that:

- In-tank coprecipitation of $\mathrm{Sr}_{3}\left(\mathrm{PO}_{4}\right)_{2}$ and $\mathrm{Fe}_{2} \mathrm{O}_{3} \cdot \mathrm{x} \mathrm{H}_{2} \mathrm{O}$ from DST CC wastes will yield LLW easily meeting NRC Class $C$ commercial waste and NRC Incidental Waste ${ }^{90} \mathrm{Sr}$ and TRU element concentration criteria.

- Organic complexants in CC waste do not have to be destroyed to accomplish sufficient removal of ${ }^{90} \mathrm{Sr}$ and TRU elements by coprecipitation of $\mathrm{Sr}_{3}\left(\mathrm{PO}_{4}\right)_{2}$ and $\mathrm{Fe}_{2} \mathrm{O}_{3} \cdot \mathrm{x} \mathrm{H}_{2} \mathrm{O}$, to meet NRC Class $\mathrm{C}$ and Incidental Waste concentration criteria.

- From an ALARA point of view, serious consideration should be given to in-tank coprecipitation of strontium phosphate, and hydrated iron oxide from all non-CC DST waste. Such action will likely remove greater than 95 percent of soluble ${ }^{90} \mathrm{Sr}$ and greater than 90 percent of soluble ${ }^{241} \mathrm{Am}$. Removal of relatively shortlived americium will substantially reduce the concentration of TRU elements in glasses made from the LLW fraction. 
WHC-SD-WM-ES-321

Revision 0

\subsubsection{Precipitation of Sodium Titanate}

The inorganic compound $\mathrm{Na}\left(\mathrm{Ti}_{2} \mathrm{O}_{5} \mathrm{H}\right)$, sodium titanate, is conveniently synthesized by the reaction (Chemical Engineering News 1976, Lynch et al. 1976):

$\mathrm{NaOH}$ (methanol) $+2 \mathrm{Ti}\left(\mathrm{OC}_{3} \mathrm{H}_{7}\right)_{4}+4 \mathrm{H}_{2} \mathrm{O}=\mathrm{Na}\left(\mathrm{Ti}_{2} \mathrm{O}_{5} \mathrm{H}\right)+8 \mathrm{C}_{3} \mathrm{H}_{7} \mathrm{OH}$.

In the early 1970's Dosch and coworkers at the DOE Sandia National Laboratory observed that preformed sodium titanate would selectively and efficiently sorb divalent strontium from simulated highly alkaline waste solutions (Lynch 1976). In the same time period, Schulz and colleagues (Schulz 1980), working with feeds prepared by dissolution of Hanford Site salt cake, confirmed Dosch's results with actual waste solutions. In batch tests with alkaline salt cake solution, Schulz (1980) found that preformed sodium titanate not only efficiently removed ${ }^{90} \mathrm{Sr}$ but also ${ }^{154} \mathrm{Eu},{ }^{239} \mathrm{Pu}$, and ${ }^{241} \mathrm{Am}$. Schulz and associates also conducted column tests with experimental lots of pelletized sodium titanate; as many as 2,000 column volumes of salt cake solution could be processed before significant breakthrough of ${ }^{90} \mathrm{Sr}$ occurred.

Current chemical flowsheets for in-tank pretreatment of alkaline waste solutions at the DOE Savannah River Site include combined precipitation of cesium tetraphenylborate to remove ${ }^{137} \mathrm{Cs}$ and sodium titanate to remove ${ }^{90} \mathrm{Sr}$ and TRU elements (d'Entremont et al. 1994). Bench-scale tests with actual DOE Savannah River Site waste solutions again demonstrated the efficient radionuclide scavenging properties of sodium titanate.

No experimental work has been performed to study sodium titanate, either preformed or precipitated in situ, scavenging of radiostrontium and TRU elements from simulated or actual Hanford Site DST waste solutions. However, previous experience at both the Hanford and Savannah River Sites strongly suggests that sodium titanate will indeed effectively remove ${ }^{90} \mathrm{Sr}$ and TRU elements from most, if not all, DST liquors. One important concern is the extent to which organic complexants in CC wastes and two of the DSSF wastes might seriously inhibit sodium titanate scavenging of radiostrontium and/or TRU elements.

One of the important recommendations (see Section 5.0) of this study is for experimental studies to determine the applicability of sodium titanate to in-tank pretreatment of Hanford Site DST liquid wastes. Concomitant with these laboratory-scale tests, engineering studies should be conducted to establish consequences to downstream vitrification of the LLW fraction of headend sodium titanate scavenging operations. These latter studies should address maximum permissible loadings of sodium titanate in vitrified LLW and compare use of sodium titanate precipitation technology to use of hydrated iron oxide and strontium phosphate precipitation schemes. 
WHC-SD-WM-ES-321

Revision 0

\subsection{PRECIPITATION REMOVAL OF TECHNETIUM-99}

The classical method for removing ${ }^{99} \mathrm{TcO}_{4}^{-}$from alkaline solutions is to sorb it on a strong base anion exchange resin. Strong (e.g., $\geq 4 M \mathrm{HNO}_{3}$ solutions are conventionally used to elute sorbed technetium. Various organic reagents (e.g., tributyl phosphate, tertiary amines, cyclohexanone, etc.) also extract $\mathrm{TcO}_{4}^{-}$from alkaline solutions. Because such separation techniques are not practical for in-tank applications, investigators at the DOE Savannah River Site in the early 1980s conducted experimental work with both simulated and actual waste solutions to explore and develop precipitation schemes for separating ${ }^{99} \mathrm{Tc}$ from such solutions. Two candidate precipitation schemes emerged from these studies.

\subsubsection{Precipitation of $\mathrm{Tc}_{2} \mathrm{~S}_{7}$}

Bibler and Wallace (1984) report that addition of a slight stoichiometric excess of $5 \mathrm{wt} \% \mathrm{Na}_{2} \mathrm{~S}$ solution to pertechnetate solutions at $\mathrm{pH}$ 6-7 caused precipitation of black $\mathrm{Tc}_{2} \mathrm{~S}_{7}$ in 95 percent yield. According to Bibler and Wallace, the molar $\mathrm{TcO}_{4}{ }^{-}$concentration must exceed $10^{-6} M$ for precipitation to occur. The Savannah River investigators also report that $\mathrm{Tc}_{2} \mathrm{~S}_{7}$ is easily filtered and may be stored as the solid or redissolved as the $\mathrm{TcO}_{4}{ }^{-}$in a $4 \mathrm{M} \mathrm{HNO}_{3}-\mathrm{H}_{2} \mathrm{O}_{2}$ solution.

The $\mathrm{pH}$ of all the DST liquid wastes is much greater than 7. Herting (1994b) did not observe any precipitate to form when $\mathrm{Na}_{2} \mathrm{~S}$ solution was added to a composite prepared from solutions in Tanks 241-AN-101, 241-AP-102, and 241-AP-106. Still, such an addition resulted in a fourfold reduction in ${ }^{99} \mathrm{Tc}$ concentration.

This latter result is encouraging enough to justify additional bench-scale tests of addition of $\mathrm{Na}_{2} \mathrm{~S}$ to actual DST waste solutions. Such tests should surely include coincident additions of a reducing agent and $\mathrm{Na}_{2} \mathrm{~S}$. In this connection, O'Kelly (1987) reports some interesting results obtained when experiments were performed at $\mathrm{pH}$ values of 6.3 and 8.5. In this case precipitates, presumably $\mathrm{Tc}_{2} \mathrm{~S}_{7}$, formed in a matter of days in synthetic brines $(5 \mathrm{M} \mathrm{NaCl})$ containing dilute concentrations of $\mathrm{TcO}_{4}{ }^{-}$and sulfide ion. In the presence of $\mathrm{Fe}$ (II), a precipitate formed which may have been $\mathrm{TcS}_{2}$ incorporated into poorly crystallized maghemite $\left(\mathrm{Fe}_{2} \mathrm{O}_{3}\right)$ and goethite $(\mathrm{FeOOH})$.

\subsubsection{Precipitation of Tetraphenylphosphonium Pertechnetate}

Walker et al. (1984) at the DOE Savannah River Site noted that the $\mathrm{TcO}_{4}^{-}$ion forms insoluble or slightly soluble precipitates with many large cations such as $\mathrm{Tl}^{+}, \mathrm{Ag}^{+}, \mathrm{Cs}^{+}$, and $\left(\mathrm{C}_{6} \mathrm{H}_{5}\right)_{4} \mathrm{As}^{+}$. Walker et al. (1984) surmised and found that the tetraphenylphosphonium ion $\left(\mathrm{TPP}^{+}\right)$forms an insoluble pertechnetate salt. Since it is less expensive and is not a suspected carcinogen, $\left(\mathrm{C}_{6} \mathrm{H}_{5}\right)_{4} \mathrm{P}^{+}$is preferred to tetraphenylarsonium ion for precipitating pertechnetate ion. 
Walker and his colleagues report that, under proper conditions, 90 percent of the $\mathrm{TcO}_{4}{ }^{*}$ in either simulated or actual alkaline waste solutions can be precipitated by TPP ${ }^{+}$. For example, 90 percent $(\mathrm{DF}=30)$ of the ${ }^{99} \mathrm{Tc}$ in a simulated waste solution containing $3.0 \mathrm{E}$ $05 \mathrm{M} \mathrm{TcO}_{4}^{-}$was precipitated by addition of $0.053 \mathrm{~g}$ of TPPCl per liter of salt solution. However, to achieve 90 percent removal of ${ }^{99} \mathrm{Tc}$ from an actual salt cake waste solution containing 2.5E-05 $\mathrm{M} \mathrm{TcO}_{4}^{-}$required $0.29 \mathrm{~g} / \mathrm{L}$ of TPPCl. Walker et al. (1984) suggest some unidentified interference in the actual waste solution may have consumed part of the TPP ${ }^{+}$ precipitant.

The DOE Savannah River Site workers observed that precipitation of TTPTcO ${ }_{4}$ did not affect any removal of fission product ruthenium, antimony, tin and iodine. They also pointed out that commercially available TPPCl can be converted to TPPOH if desired to avoid possible corrosion problems occasioned by the presence of chloride ion.

Judging from the very preliminary Savannah River Site results, precipitation of TTPTCO ${ }_{4}$ may be a suitable method for removing ${ }^{99} \mathrm{Tc}$ from Hanford Site DST waste solutions. However, much experimental work (see Section 5.0) needs to be done with both simulated and actual waste liquors to determine the applicability of TPP ${ }^{+}$to removal of technetium from Hanford Site wastes. These experiments must be designed to answer questions concerning effects and interactions of $\mathrm{TCO}_{4}^{-}, \mathrm{OH}^{-}$, and TPP ${ }^{+}$concentrations on technetium removal efficiency. Tests need also to be performed to determine if $\mathrm{TPPTcO}_{4}$ can be precipitated along with strontium phosphate and hydrated iron oxide. Such coprecipitation schemes are desirable to provide a filter aid to agglomerate the finely-divided $\mathrm{TPPTcO}_{4}$ precipitate and expedite solid-liquid separations.

Safety concerns associated with the behavior of tetraphenylphosphonium pertechnetate precipitates during HLW vitrification operations need to be examined also. In particular, it is essential to avoid generation and release of toxic benzene to the environment.

\subsection{SORPTION REMOVAL OF STRONTIUM-90, TRANSURANIC ELEMENTS, AND TECHNETIUM-99}

When designed and constructed, the shielded, out-of-tank, facility for ion exchange removal of ${ }^{137} \mathrm{Cs}$ from alkaline Hanford Site waste solutions will likely provide for possible installation and operation of sorption systems for removal of ${ }^{90} \mathrm{Sr}$, TRU elements, and ${ }^{99} \mathrm{Tc}$. Candidate sorbents for removal of these radionuclides are briefly mentioned and discussed.

\subsubsection{Sorption of Cesium-137, Strontium-90, and Transuranic Elements}

Candidate organic cation exchange resins, either phenol- or resorcinol-based, for removal of ${ }^{137} \mathrm{Cs}$ are highly selective for radiocesium and are not considered particularly useful for removal of either ${ }^{90} \mathrm{Sr}$ or TRU elements. 
Sandia National Laboratory (SNL) investigators (Dosch 1993, Klavetter 1994a, Klavetter 1994b) have proposed use of an inorganic sorbent; crystalline silicotitanate (CST), for effective removal of radiocesium from Hanford Site alkaline waste solutions. The SNL interest in synthesis and characterization of CST grew naturally out of their earlier experience with amorphous sodium titanate and their desire to produce a crystalline exchanger. The SNL investigators report that CST has a very high affinity and selectivity for ${ }^{137} \mathrm{Cs}$ from alkaline solutions. Although not conclusively established, the CST material by analogy to sodium titanate, may also be capable of sorbing ${ }^{90} \mathrm{Sr}$ and TRU elements, as well as ${ }^{137} \mathrm{Cs}$, from Hanford Site alkaline waste solutions. If so, a single bed of CST could be used in the shielded facility to simultaneously remove ${ }^{137} \mathrm{Cs}$, ${ }^{90} \mathrm{Sr}$, and TRU elements. Potential disadvantages of the use of CST material include its current unavailability in a form considered suitable for acceptable hydraulic performance in plant-scale columns and the absence of any simple way of achieving elution and regeneration of loaded beds.

E. P. Horwitz at Argonne National Laboratory (ANL) in collaboration with Prof. S. Alexandratos at the University of Tennessee report that they have developed an organic resin specifically designed to selectively and simultaneously remove ${ }^{137} \mathrm{Cs}$, ${ }^{90} \mathrm{Sr}$, and TRU elements from aqueous $\mathrm{NaOH}$ solutions. Studies with this new ion exchange resin are in the very early stages, but preliminary results, according to Horwitz, show the expected and desired affinities and selectivities. Horwitz states that loaded beds of the new resin can be regenerated by simple elution procedures. He also believes that the new organic resin can be readily manufactured in quantities needed for plant-scale application. Further details of the synthesis and properties of the new resin are currently not available because of its very recent development and because of patentability restrictions.

\subsubsection{Sorption of Technetium-99}

Sorption of $\mathrm{TCO}_{4}{ }^{-}$onto strong base anion exchange resins is the classical method for removal of technetium from alkaline waste solutions (Roberts et al. 1962). Recent investigations of this ion exchange procedure with both simulated and actual waste solutions have been performed by Schulz (1980), Walker et al. (1984), and Schroeder (1994). A major disadvantage of this separations technology is that sorbed ${ }^{99} \mathrm{Tc}$ can only be eluted from the anion exchange resin with strong (i.e., $>4 \mathrm{MHNO}_{3}$ ) acid solutions. Treatment of large volumes of eluate to recover $\mathrm{HNO}_{3}$ for reuse is cumbersome and expensive.

What appears to be a significant breakthrough in the sorption chemistry of ${ }^{90} \mathrm{TcO}_{4}{ }^{-}$has been recently achieved by E. P. Horwitz at ANL in collaboration with Prof. R. Rogers of Northern Illinois University. Horwitz and Rogers have synthesized an organic ion exchange resin that, in preliminary tests, shows very high affinity $\left(D_{T_{c}}>100\right)$ and selectivity for $\mathrm{Tc}$ (VII) from simulated alkaline waste solutions. ${ }^{8}$ Preliminary work also indicates that $\mathrm{TcO}_{4}{ }^{\circ}$

${ }^{8}$ Patent application restrictions prevent disclosure, at this time, of the details of synthesis of the new technetium-specific resin. 
can be readily stripped from the new resin with water or dilute $\mathrm{HNO}_{3}$ solutions. Horwitz and Rogers do not foresee any difficulty in manufacture of large quantities of the new Technetium-specific resin.

Horwitz and Rogers also suggest that it may eventually be possible to combine the technetium-selective resin with the new cesium-strontium-TRU-selective resin described in the previous section to provide a mixed resin bed highly useful for decontaminating alkaline Hanford Site waste solution in a single ion exchange process.

\subsection{DESTRUCTION OF ORGANIC COMPLEXANTS}

\subsubsection{Introduction}

Five of the DSTs contain liquid waste whose content of total organic carbon exceeds $22 \mathrm{~g} / \mathrm{L}$ (Table 3-1). Two other DSTs (Tanks 241-AY-101 and 241-SY-103) contain waste classified as CC wastes. In-tank destruction of some or all of the organic complexants present in these seven DSTs may be necessary to achieve necessary or desired removal of ${ }^{90} \mathrm{Sr}$ and/or TRU elements. Data presented in Section 4.2 show that hydrated iron oxide and strontium phosphate precipitation removal of radiostrontium and TRU elements is considerably less effective with CC wastes than with DST wastes containing only small amounts of aqueous soluble organic compounds.

Much effort in the last 10 to 15 years has been devoted to consideration and evaluation of different technologies for destruction of organic complexants in Hanford Site DST and SST wastes. Among the technologies proposed for this purpose are as follows:

- Calcination

- Plasma Arc Destruction

- Electrooxidation

- Photolysis (with ultraviolet light)

- Wet Air Oxidation

- Hydrogen Peroxide Oxidation (in acid medium)

- Ozonation

- Thermolysis (at or below $100^{\circ} \mathrm{C}$ ).

Of these candidate methods, only ozonation and low temperature thermolysis can be seriously considered for use in in-tank applications to DST wastes. The status of development of ozonolysis and low-temperature thermolysis processes for destruction of organic complexants is reviewed and discussed in Sections 4.5.2.1 and 4.5.2.2. Anticipating these latter discussions, successful implementation of an in-tank ozonation process would require resolution of some major engineering and potential tank corrosion issues. Presently, 
therefore, low temperature thermal treatment is the preferred method for in-tank destruction of organic compounds.

\subsubsection{Thermal Destruction of Organic Complexants}

4.5.2.1 Historical Background. Episodic releases of hydrogen and other gases from one of the CC waste tanks, Tank 241-SY-101, were observed in the late 1970's, soon after transferring the CC waste into the tank. Shortly thereafter, Delegard (1980) conducted bench-scale studies with simulated Tank 241-SY-101 waste to seek the cause and nature of the gas releases. Delegard quickly established that, under the conditions existing in Tank 241-SY-101, certain of the organic complexants, notably glycolate and HEDTA, were undergoing thermal and radiolytic degradation to produce hydrogen, $\mathrm{N}_{2} \mathrm{O}$, and other gases as well as a host of aqueous-soluble organic compounds. The finely-divided bubbles of gas were physically trapped by the sludge in Tank 241-SY-101; periodically, when gas buoyancy forces exceeded gravity forces, the accumulated gases were released over a short time period. Delegard also noted that certain organic complexants (e.g., EDTA and nitrilotriacetic acid [NTA]) were more resistant to thermal degradation than HEDTA and glycolate.

In the last five years, triggered by heightened safety concerns about Tank 241-SY-101, a great many experimental studies with both simulated and actual Tank 241-SY-101 waste have been performed by investigators at Westinghouse Hanford Company, Pacific Northwest Laboratory, Argonne National Laboratory, and Georgia Institute of Technology. These studies, primarily of a fundamental nature, sought to identify and quantify reaction products and mechanisms for thermal and radiolytic attack of various organic complexants, singly or in admixture. Results of these studies have been extensively documented (Ashby et al. 1993, Babad et al 1992, Meisel et al. 1993, Babad et al. 1991, Strachan 1991a, Strachan 1991b, Strachan 1992, Strachan 1993). Readers interested in the details of these fundamental studies should consult the reports and papers cited.

4.5.2.2 Thermal Oxidation Studies. With the goal of achieving complete or, at least, partial destruction of organic complexants in CC waste, several investigators have recently conducted thermal (better, hydrothermal) studies at various temperatures with both simulated and actual CC wastes. Successful oxidation of organic complexants in these thermal studies was anticipated from the observed behavior of wastes in Tank 241-SY-101.

Orth et al. (1993) heated simulated Tank 241-SY-101 waste containing various organic complexants at $200{ }^{\circ} \mathrm{C}$ for various times. He observed rapid oxidation of HEDTA and glycolate at $200^{\circ} \mathrm{C}$. Orth (1993) also found that at $200^{\circ} \mathrm{C}$ EDTA decomposed at a reasonable rate but that NTA did not. A temperature of $250^{\circ} \mathrm{C}$ was required before NTA was oxidized at an appreciable rate. Los Alamos National Laboratory workers also conducted hydrothermal tests with simulated Tank 241-SY-101 waste solution at temperatures above $250^{\circ} \mathrm{C}$. 
For safety and other reasons, in-tank thermal oxidation of organic complexants in CC wastes should be limited to temperatures no higher than about 100 to $120^{\circ} \mathrm{C}$. Thus, the Pacific Northwest Laboratory and Los Alamos National Laboratory tests at temperatures of $200{ }^{\circ} \mathrm{C}$ and above, although interesting for the knowledge they provide, do not apply to in-tank thermal destruction of organic complexants. Much more applicable are the results obtained by Person in experiments with actual wastes from Tanks 241-SY-101 and 241-AN-107.

Person and Colton (1993) are performing "heat and digest" experiments with actual DST CC wastes to determine the length of time required at 100 and $120^{\circ} \mathrm{C}$ before gas evolution ceases. The primary goal of Person's studies is to establish if low-temperature digestion of CC wastes will mitigate associated safety issues by sufficiently accelerating the rate of organic destruction over what it is at the present tank temperature of about $65{ }^{\circ} \mathrm{C}$.

Person's initial experiments were performed with a composite of liquid samples from Tank 241-SY-101. Separate waste samples were heated at $65^{\circ} \mathrm{C}$ for periods of 30 and 34 days. Subsequently, the sample heated 30 days was heated an additional 73 days at $100{ }^{\circ} \mathrm{C}$. Person observed that the gas generation rate at $65^{\circ} \mathrm{C}$ was approximately the same as observed in Tank 241-SY-101. At $100{ }^{\circ} \mathrm{C}$ the gas generation rate was about 24 times that at $65{ }^{\circ} \mathrm{C}$ corresponding to an activation energy of about $23 \mathrm{Kcal} / \mathrm{mol}$.

At $65{ }^{\circ} \mathrm{C}$ the generated gas contained approximately (all vol\%) 48 percent $\mathrm{H}_{2}$, 29 percent $\mathrm{N}_{2}, 19$ percent $\mathrm{N}_{2} \mathrm{O}, 1.7$ percent $\mathrm{CH}_{4}$, and 0.4 percent $\mathrm{NH}_{3}$. At $100{ }^{\circ} \mathrm{C}$ gas was generated rapidly until after 15 days when the gas generation rate remained essentially constant at $0.65 \mathrm{~mol} / \mathrm{L} / \mathrm{day}$. The offgas at $100^{\circ} \mathrm{C}$ contained (all vol\%) 25 to 27 percent $\mathrm{H}_{2}$, 25 to 27 percent $\mathrm{N}_{2}, 25$ to 27 percent $\mathrm{N}_{2} \mathrm{O}, 5$ to 8 percent $\mathrm{CH}_{4}$, and 3 to 17 percent $\mathrm{NH}_{3}$.

The portion of Tank 241-SY-101 waste initially heated at $65^{\circ} \mathrm{C}$ and then heated for 73 days at $100{ }^{\circ} \mathrm{C}$ was analyzed for free $\mathrm{OH}^{-}$, total organic carbon (TOC), and total inorganic carbon (TIC) and the results compared to data for unheated waste. The TOC decreased by 24 percent and the free $\mathrm{OH}^{-}$by 11 percent while the TIC was unchanged. Concentrations of individual complexants (e.g., HEDTA, EDTA, NTA, etc.) before and after heating tests were not determined. Attempts to discern changes, if any, in concentrations of ${ }^{90} \mathrm{Sr}$ and TRU elements failed primarily because of the low concentrations of these nuclides in the unheated waste (see Table 3-1).

Person and Colton (1993) are currently studying effects of heating supernatant liquid from Tank 241-AN-107 (CC waste) at $100{ }^{\circ} \mathrm{C}$. Two tests are in progress, one with undiluted Tank 241-AN-107 solution and one with Tank 241-AN-107 liquor to which additional $\mathrm{NaOH}$ and $\mathrm{NaAlO}_{2}$ have been added. Both solutions have been heated 31 days. In both cases the rate of gas generation for the first 31 days of heating is noticeably fast. Person and Colton (1993) plan to continue heating both samples of Tank 241-AN-107 waste for an indefinite time. Periodically, they plan to take samples of the digested waste to 
determine ${ }^{90} \mathrm{Sr}$ and TRU element concentrations as well as concentrations of TOC, TIC, and free $\mathrm{OH}^{-}$.

\subsubsection{Status and Evaluation of Low-Temperature Thermal Oxidation of Organic} Complexants. Person's scouting tests with solutions from Tanks 241-SY-101 and 241-AN-107 surely show, as fully expected, that thermal treatment of CC wastes at $100{ }^{\circ} \mathrm{C}$ oxidizes organic complexants and at a rate faster than at the nominal tank temperature of $65^{\circ} \mathrm{C}$. However, unfortunately, these scouting tests are only scouting tests. Many important questions remain unanswered, such as:

- Exactly which complexants are being oxidized--all or only particular ones?

- How does heating $\mathrm{CC}$ wastes at $100{ }^{\circ} \mathrm{C}$ affect the behavior of ${ }^{90} \mathrm{Sr}$ and TRU elements--during both the heating step and in subsequent in-tank precipitation of strontium phosphate and/or hydrated iron oxide?

- How long must heating be continued to oxidize those complexants that interfere with removal of radiostrontium and TRU elements?

Clearly, much more bench-scale work is needed before in-tank destruction of organic complexants can be identified as a viable technology. For reasons already mentioned (Section 1.5.2), it is important that "heat and digest" tests be performed with waste from each of the five CC DSTs and also from Tanks 241-AN-104 and 241-AN-105; the latter two tanks also contain high concentrations of soluble organic materials.

4.5.2.4 Safety and Other Considerations. Assuming a favorable outcome to further tests of low temperature thermal destruction of organic complexants in DST wastes, there are a number of safety and other concerns that must be resolved before such a process could be implemented in DSTs. These include:

- Capacity of the DST ventilation system to accommodate increased gas flows. If heating is achieved by passing hot gas through the ullage space of the tank, major modifications to the tank ventilation system may be necessary.

- Increased gas generation rates might lead to increased entrapment of flammable gases in the few DSTs having a high solids content. Reliable agitation, either continuous or intermittent, of tank contents will have to be provided to avoid unsafe rapid release of flammable gases.

- Excessive corrosion of the inner DST steel liner during prolonged "heat and digest" operations must be avoided. In particular, nitrite and free hydroxide ion concentrations would have to be carefully monitored and, if necessary, adjustments made during the digestion period. 


\section{WHC-SD-WM-ES-321}

Revision 0

- Prolonged heating of DST CC waste at $100{ }^{\circ} \mathrm{C}$ will not completely oxidize all organic material to carbon dioxide and water. Some of the complexants may be unchanged while others, perhaps many, will only be oxidized to lower molecular weight fragments. Some of these organic fragments may exhibit unsafe exothermic behavior when heated at $100^{\circ} \mathrm{C}$. More information as to the identity and properties of refractory organic substances produced during or resulting from prolonged thermal treatment must be obtained.

- Residual organic compounds that remain, even after prolonged digestion of DST wastes at elevated temperature, could likely have a deleterious effect upon operation of a Joule-heated glass melter used to vitrify the LLW fraction. The presence of such compounds, even in treated $\mathrm{CC}$ wastes, must be considered when selecting equipment for vitrification of LLW wastes.

\subsubsection{Ozonolysis of Complexants}

Ozone $\left(\mathrm{O}_{3}\right)$ is a very powerful oxidant in both alkaline and acidic media and is easily capable of oxidizing large molecules of aminopolycarboxylates to smaller molecules of socalled refractory compounds such as oxalate and acetate. For this purpose, ozone is an attractive reagent since it does not add additional metal ions to a waste solution.

Schulz and his colleagues performed initial scouting experiments of ozonolysis of actual Hanford CC-type waste solutions in the late 1970s (Schulz 1980, Lutton et al. 1979, Winters 1981). Even with a very inefficient gas-liquid contacting system, Schulz (1980) found that organic complexants in $\mathrm{CC}$ waste solutions were successfully oxidized by reaction with $\mathrm{O}_{3}$ at 20 to $25^{\circ} \mathrm{C}$. Such treatment resulted in a substantial decrease in the TOC of the test solutions and in precipitation of soluble Fe(III) as hydrated iron oxide which scavenged some ${ }^{90} \mathrm{Sr}$ and TRU elements.

More recently, Delegard et al. (1993) again investigated use of ozone to oxidize organic complexants in alkaline salt waste solutions. These investigators took careful pains to design and employ a highly efficient flow device for effecting intimate contact of the dissolved complexants with ozone. Delegard and colleagues observed that, as expected from known oxidation potentials, ozone quantitatively and preferentially oxidized nitrite ion in test solutions to nitrate ion. Once nitrite oxidation was complete, ozone rapidly and vigorously attacked organic complexants. In the test equipment used by Delegard et al. (1993) organic complexants were converted to refractory oxalate and acetate ions in as little as eight hours at 22 to $25^{\circ} \mathrm{C}$.

At least two major problems have to be resolved to accomplish in-tank ozonolysis of complexants in $\mathrm{CC}$ waste solutions. Equipment to provide for highly efficient contact of ozone with liquid waste in all parts of a large DST would have to be designed, constructed, and emplaced. An even more difficult problem is how to protect the DST walls and weldments against stress cracking during what might be prolonged ozonation periods. 
WHC-SD-WM-ES-321

Revision 0

Presently, substantial concentrations of nitrite ion in the alkaline waste provide sufficient protection against stress cracking phenomena. Conversion of nitrite ion to nitrate ion in the early part of the ozonation operation would leave the DST reaction vulnerable to unacceptable corrosion damage. 


\section{WHC-SD-WM-ES-321}

\section{Revision 0}

This page intentionally left blank. 
WHC-SD-WM-ES-321

Revision 0

\subsection{RECOMMENDED FOLLOW-ON BENCH-SCALE STUDIES}

\subsection{INTRODUCTION}

Herting's (1994b) encouraging, but preliminary, batch precipitation tests with liquid from Tank 241-AN-107 (CC waste) indicate that in-tank precipitation of hydrated iron oxide and/or strontium phosphate from such wastes will remove at least 84 to 96 percent of the TRU elements and ${ }^{90} \mathrm{Sr}$ from CC waste liquors. From non-CC DST wastes precipitation of these scavenging agents will remove even more (e.g., approximately 99 percent) of the TRU elements and radiostrontium. Additional experimental work is needed to establish, unequivocally, applicability of this precipitation approach to removal of TRU elements and ${ }^{90} \mathrm{Sr}$ from all DST wastes. Bench-scale tests of other candidate precipitation agents (e.g., sodium titanate) for removal of radiostrontium and TRU elements from various kinds of DST waste also need to be performed.

Demonstrated technology for in-tank precipitation removal of ${ }^{99} \mathrm{Tc}$ from DST waste liquors is nonexistent. Several precipitation schemes which may be useful for this purpose are reported in the technical literature. Appropriate bench-scale tests with representative DST wastes should be performed to develop and demonstrate viable technology for reducing the technetium concentration of DST wastes.

Of several known technologies for oxidizing organic chelating agents, only simple lowtemperature thermal destruction techniques appear suitable for in-tank destruction of organic complexing agents in DST wastes. Thermal destruction of HEDTA and other complexing agents proceeds rapidly at elevated temperature (i.e., $>200^{\circ} \mathrm{C}$ ). At $100^{\circ} \mathrm{C}$, a temperature potentially suitable for in-tank operations, Person (1994) finds that destruction of organic complexants in CC waste from Tank 241-SY-101 proceeds but at a rate considerably slower than at higher temperatures. Thermal destruction tests at $100{ }^{\circ} \mathrm{C}$ are just underway. Presently unknown is precipitation behavior of ${ }^{90} \mathrm{Sr}$ and TRU elements as a function of the time DST waste containing organic complexants is heated at $100^{\circ} \mathrm{C}$. Also, unknown, is the extent to which ${ }^{90} \mathrm{Sr}$ and TRU elements in DST wastes heated at $100{ }^{\circ} \mathrm{C}$ for prolonged times can be removed by precipitation of hydrated iron oxide and/or strontium phosphate.

\subsection{SPECIFIC RECOMMENDED FOLLOW-ON BENCH-SCALE TESTS}

Follow-on bench-scale tests specifically recommended for completion are listed below. Data from these tests are required to properly evaluate the technical viability and capability of various in-tank processes and to select process conditions for plant-scale implementation. 
WHC-SD-WM-ES-321

Revision 0

\subsubsection{Precipitation-Scavenging Tests}

Perform the following precipitation-scavenging test.

1. Perform batch hydrated iron oxide and/or strontium phosphate precipitation tests with all CC wastes in the DSTs to optimize conditions for removal of TRU elements and ${ }^{90} \mathrm{Sr}$. It is particularly desireable to minimize the quantities of precipitated $\mathrm{Sr}_{3}\left(\mathrm{PO}_{4}\right)_{2}$ and $\mathrm{Fe}_{2} \mathrm{O}_{3} . \mathrm{x} \mathrm{H}_{2} \mathrm{O}$ to minimize the overall volume of vitrified $\mathrm{HLW}$. Batch precipitation studies should also include determination of the behavior of $\mathrm{Sr}_{3}\left(\mathrm{PO}_{4}\right)_{2}$ and $\mathrm{Fe}_{2} \mathrm{O}_{3} . \times \mathrm{H}_{2} \mathrm{O}$ precipitates during subsequent waste retrieval and sludge washing operations.

2. Perform batch hydrated iron oxide and/or strontium phosphate studies with 10 to 15 liquid wastes from DSTs containing non-CC wastes to optimize conditions for removal of TRU elements and ${ }^{90} \mathrm{Sr}$.

3. Perform a series of batch precipitation tests with actual DST waste solutions to determine if the less expensive $\mathrm{Ca}\left(\mathrm{NO}_{3}\right)_{2}$ can be substituted for $\mathrm{Sr}_{3}\left(\mathrm{NO}_{4}\right)_{2}$ to achieve the desired removal of ${ }^{90} \mathrm{Sr}$.

4. Investigate, in batch-scale tests, the capabilities of sodium titanate, both preformed and precipitated in situ, for removing radiostrontium and TRU elements from DST liquid wastes containing both low and high concentrations of organic compounds.

5. Conduct preliminary bench-scale tests to determine if technetium sulfide can be precipitated from DST wastes, both CC and other types. If scouting tests warrant, conduct more extensive bench-scale tests to establish optimum conditions for removal of ${ }^{99} \mathrm{Tc}$ both with and without concurrent precipitation of hydrated iron oxide and/or strontium phosphate.

6. Conduct preliminary bench-scale tests to determine if tetraphenylphosphonium pertechnetate can be precipitated from DST wastes. If initial scouting tests are favorable, perform additional bench-scale tests, both in the presence and absence of hydrated iron oxide and strontium phosphate precipitates, with a variety of DST wastes to establish optimum conditions for in-tank implementation. 


\section{Revision 0}

\subsubsection{Sorption Tests}

Perform the following sorption tests.

1. Conduct batch and, if warranted, column tests to determine the capability of CST sorbents for simultaneously removing ${ }^{137} \mathrm{Cs},{ }^{90} \mathrm{Sr}$, and TRU elements from DST liquid waste solutions.

2. Closely monitor progress of ANL development and testing of a new organicbased resin which offers the potential for co-sorption of ${ }^{137} \mathrm{Cs},{ }^{90} \mathrm{Sr}$, and TRU elements. If future ANL results warrant, conduct bench and column-scale. tests of the new resin with actual Hanford Site DST wastes.

3. Closely follow status and progress of ANL scientists in synthesizing and testing a new technetium-specific organic ion exchange resin. If ANL test results continue favorable, conduct bench- and column-scale tests of the new resin with actual Hanford Site DST wastes.

\subsubsection{In-Tank Thermal Destruction of Organic Complexants}

Conduct the following experiments for in-tank thermal destruction of organic complexants.

1. Complete on-going experiments to determine the extent and rate of thermal destruction, at $100^{\circ} \mathrm{C}$, of organic complexants in liquid waste from Tank 241 AN-107. Establish exactly which complexants are being destroyed and how long a digestion time is required to significantly enhance precipitation removal of ${ }^{90} \mathrm{Sr}$ and TRU elements, either with or without addition of hydrated iron oxide, or strontium phosphate, or sodium titanate.

2. Conduct thermal degradation experiments similar to those with Tank 241-AN-107 waste solution with waste solutions from other DSTs containing high concentrations of organic material. 
WHC-SD-WM-ES-321

Revision 0

This page intentionally left blank. 
WHC-SD-WM-ES-321

Revision 0

\subsection{REFERENCES}

10 CFR 61, 1992, Licensing Requirements for Land Disposal of Radioactive Waste, U.S. Code of Federal Regulations, U.S. Nuclear Regulatory Commission, Washington, DC.

10 CFR 61, 1988, Licensing Requirements for Land Disposal of Radioactive Waste, U.S. Code of Federal Regulations, U.S. Nuclear Regulatory Commission, Washington, DC.

Alumkal, W. T., July 18, 1994, Configuration Selection for the Tank Waste Remediation System, Letter to T. R. Sheridan, U.S. Department of Energy Richland Operations Office, Richland, Washington.

Ashby, E. C., F. Doctorvitch, C. L. Liotta, H. M. Neumann, E. K. Barefield, A. Konda, K. Zhang, J. Hurley, and D. Siemer, 1993, Concerning the Formation of Hydrogen in Nuclear Waste, Quantitative Generation of Hydrogen via a Cannizzaro Intermediate, J. American Chemical Society, 115

Babad, H., et al., 1991, Evaluation of the Generation and Release of Flammable Gases in Tank 241-SY-101, WHC-EP-0517, Westinghouse Hanford Company, Richland, Washington.

Babad, H., G. D. Johnson, D. A. Reynolds, and D. M. Strachan, 1992, Understanding of Cyclic Phenomena in Hanford Site High-Level Waste Tanks: The Evaluation of Tank 241-SY-101, WHC-SA-1364-FP, Westinghouse Hanford Company, Richland, Washington.

Bernero, R. M., 1989, Letter to A. J. Rizzo, U.S. Department of Energy, Richland Operations Office, Richland, Washington, September 26, I989, U.S. Nuclear Regulatory Commission, Washington, DC.

Bernero, R. M., 1993, Letter to J. Lytle, U.S. Department of Energy, Richland Operations Office, Richland, Washington, March 2, 1993, U.S. Nuclear Regulatory Commission, Washington, DC.

Bibler, J. P. and R. M. Wallace, 1984, Precipitation Methods of Recovery of Tc-99 from Soluble Waste, DPST-84-707, E. I. du Pont de Nemours \& Co., Aiken, South Carolina. 


\section{WHC-SD-WM-ES-321}

Revision 0

Boomer, K. D., J. M. Colby, T. W. Crawford, J. S. Garfield, J. D. Galbraith, C. E. Golberg, C. E. Leach, D. E. Mitchell, F. D. Nankani, E. J. Slaathaug, L. M. Swanson, T. L. Waldo, and C. M. Winkler, 1994, Tank Waste Remediation System Facility Configuration Study, WHC-ED-WM-ES-295, Rev 0, Westinghouse Hanford Company, Richland, Washington.

Brown, R. C., 1993, Radiological Implication Contact Maintenance, WHC-SD-WM-TF-607, Westinghouse Hanford Company, Richland, Washington.

Campbell, J. A., et al., 1993, Flammable Gas Safety Program Analytical methods Development: FY 1993 Progress Report, Pacific Northwest Laboratory, Richland, Washington.

Chem Eng. News, 1976, 54 (No. 2), 32.

Delegard, C. H., 1980, Laboratory Studies of Complexed Waste Slurry Volume Growth in Tank 241-SY-101, RHO-LD-124, Rockwell Hanford Company, Richland, Washington.

Delegard, C. H., A. M. Stubbs, and S. D. Bolling, 1993, Laboratory Testing of Ozone Oxidation of Hanford Site Waste from Tank 241-SY-101, WHC-EP-0701, Westinghouse Hanford Company, Richland, Washington.

Dosch, R. G., N. E. Brown, H. P. Stephens, and R. G. Anthony, Treatment of Liquid Nuclear Wastes with Advanced Forms of Titanate Ion Exchanger, Waste Management 93-1751, Tucson, Arizona.

d'Entremont, P. D., R. A. Jacobs, J. R. Fowler, D. F. Brown, D. J. McCabe, D. D. Walker, and J. M. Gilliam, 1994, High-Level Waste System Process Interface Description--Functions and Requirements of the High-Level Waste Process (U), WSRC-TR-94-0442, Rev. 0, Westinghouse Savannah River Company, Aiken, S.C.

Herting, D. L., 1993, Effect of Tank 107-AN Caustic Addition on Radionuclide Solubilities, Internal Memo 12110-PCL93-043, Westinghouse Hanford Company, Richland, Washington.

Herting, D. L., 1994a, Strontium Removal Study--Feed Characterization, Internal Memo 12110-PCL-94-017, Westinghouse Hanford Company, Richland, Washington.

Herting, D. L., 1994b, Strontium Removal by Precipitation, Internal Memo 12110-PCL94-026, Westinghouse Hanford Company, Richland, Washington.

Johnson, M. E., 1985, Strontium Ion Exchange Feasibility Study, SD-WM-ER-018, Rev. 0, Rockwell Hanford Company, Richland, Washington. 
Johnson, M. E., 1994, Use of Organic Complexants During Cesium Ion Exchange Process, Internal Memo 7B100-MEJ-002, Westinghouse Hanford Company, Richland, Washington.

Kurath, D. E., 1993, Analysis of Equilibrium Data for Cesium Ion Exchange of Hanford CC and NCAW Supernatant Liquid--Status Report, TWRSPP-93-051, Battelle Pacific. Northwest Laboratory, Richland, Washington.

Klavetter, E. A., N. E. Brown, D. E. Trudell, R. G: Anthony, D. Gu, C. Thibaud-Erkey, 1994a, Ion-Exchange Performance of Crystalline Silicotitanates for Cesium Removal from Hanford Tank Waste Simulants, Waste Management 94-709, Tucson, Arizona.

Klavetter, E. A., N. E. Brown, D. E. Trudell, Z. Zheng, R. G. Anthony, D. Gu, C. Thibaud-Erkey, 1994b, Performance of Crystalline Silicotitanates for Cesium Removal from Hanford Tank Waste Simulants, American Chemical Society Meeting, Washington, D. C.

Lutton, T. W., W. W. Schulz, D. M. Strachan, and L. J. Bollyky, 1979, Ozone: Science and Engineering, Vol. 1, 133.

Lynch, R. W., Ed., 1976, U.S. Energy Research and Development Report, SAND-76-0105, Sandia Laboratories, Albuquerque, New Mexico.

Meisel, D., C. D. Jonah, S. Kapoor, M. S. Matheson, and M. C. Sauer, 1993, Radiolytic and Radiolytically-Induced Generation of Gases from Synthetic Wastes--Final Report, ANL-93/XX, Argonne National Laboratory, Argonne, Illinois.

O'Kelley, G. D., 1987, Solubility Issues Related to the Performance of a High Level Nuclear Waste Repository in Bedded Salt: A Survey of Data Needs for Solubilities and Aqueous Species of Technetium, Radium, and Iodine, ORNL/TM-10510, Oak Ridge National Laboratory, Oak Ridge, Tennessee.

Orth, R. D., 1993, Annual Report, Hydrothermal Processing of Hanford Tank Waste-Organic Destruction Technology Development Tank, TWRS-PP-93-04, Pacific Northwest Laboratory, Richland, Washington.

Payne, K. L., 1983, Purification of Strontium by Ion Exchange, Internal Memo 659920-83-173, Rockwell Hanford Company, Richland, Washington. 
Person, J. C. and N. G. Colton, 1993, "Organic Destruction Development: Laboratory Testing--Heat and Digest, " in Evaluation of Alternative Technologies for the Destruction of Organics and Ferrocyanides in Hanford Tank Waste: Corona Discharge, Heat and Digest, Electrochemical Oxidation, TWRSPP-93-070, Battelle Pacific Northwest Laboratory, Richland, Washington.

Person, J. C., 1994, Organic Destruction Technology Development: Laboratory Testing-Heat and Digest, Internal Memo 12110-PCL94, Westinghouse Hanford Company, Richland, Washington.

Roberts, F. P., F. M. Smith, and E. J. Wheelwright, 1962, Recovery and Purification of Technetium-99 from Neutralized PUREX Waste, HW-SA-2581, General Electric Company, Richland, Washington.

Ryan, J. L., 1992, Thermal Degradation of Organics in High-Level Waste Tanks, Letter to A. L. Boldt, Battelle Pacific Northwest Laboratory, Richland, Washington.

Schroeder, N., 1994, Technetium Partitioning for the Hanford Tank Waste Remediation System: Sorption and Extraction of Technetium from Simple Caustic Solutions, LA-UR94-62, Los Alamos National Laboratory, Los Alamos, New Mexico.

Schulz, W. W., 1980, Removal of Radionuclides from Hanford Defense Waste Solutions, RHO-SA-51, Rockwell Hanford Operations, Richland, Washington.

Shelton, L. W., 1995, Double-Shell Tank Inventories, Internal Memo 71320-95-003, Westinghouse Hanford Company, Richland, Washington.

Strachan, D. M., 1991a, Minutes of the Tank Waste Science Panel Meeting, November 11-13, 1991, PNL-8048, Pacific Northwest Laboratory, Richland, Washington.

Strachan, D. M., 1991b, Minutes of the Tank Waste Science Panel Meeting, July 9-11, 1991, PNL-8047, Pacific Northwest Laboratory, Richland, Washington.

Strachan, D. M. and W. W. Schulz, 1992, Minutes of the Tank Waste Science Panel Meeting, March 25-27, 1992, PNL-8278, Pacific Northwest Laboratory, Richland, Washington.

Strachan, D. M. and W. W. Schulz, 1993, Minutes of the Tank Waste Science Panel Meeting, January 12-13, 1993, PNL-8845, Pacific Northwest Laboratory, Richland, Washington. 
Walker, D., J. P. Bibler, R. M. Wallace, M. A. Ebra, and J. P. Ryan, Jr., 1984, Technetium Removal Processes for Soluble Defense High-Level Waste, DP-MS-84-85, E. I. du Pont de Nemours Co., Aiken, South Carolina.

Washington, L. O., 1990, Chemical Addition to Tank 107-AN, Internal Memo 16220-PCL90-079, Westinghouse Hanford Company, Richland, Washington.

Winters, W. I., 1981, Effect of pH on the Destruction of Complexants with Ozone in Hanford Nuclear Waste, RHO-SA-203, Rockwell Hanford Operations, Richland, Washington.

Wodrich, D. D., 1994, The Hanford Site Tank Waste Remediation System Technical Strategy, WHC-SA-2335-FP, Westinghouse Hanford Company, Richland, Washington. 
WHC-SD-WM-ES-321

Revision 0

This page intentionally left blank. 
WHC-SD-WM-ES-321

Revision 0

\section{APPENDIX A}

\section{ORGANIC COMPONENTS PRESENT IN TANK 241-SY-101 WASTE}

Tables A-1 and A-2, reproduced from a recent report by Campbell et al. (1994), list some of the organic chelators and chelator fragments identified in the liquid waste in Tank 241-SY-101. In addition to the analytes listed in Tables A-1 and A-2, many minor components including nitroso compounds are also present in Tank 241-SY-101 waste. 
WHC-SD-WM-ES-321

Revision 0

Table A-1. Results of Derivatization ${ }^{(a)}$ GC/MS Analyses on Tank 241-101-SY Window E

Core Segment Samples Concentration of Major Components (mg Carbon/g Sample)

\begin{tabular}{|l|c|c|c|c|c|c|c|c|c|}
\hline Sample \# & NIDA & NTA & CA & ED3A $^{(0)}$ & EDTA & HEDTA $^{(c)}$ & SA & $\begin{array}{c}\text { TOC } \\
\text { Accounted } \\
\text { For }^{(d)}\end{array}$ & $\begin{array}{c}\text { Percent TOC } \\
\text { Accounted } \\
\text { For }\end{array}$ \\
\hline R4258/C & 1.30 & 0.40 & 0.44 & 0.19 & 2.00 & - & 0.07 & 4.8 & 44 \\
\hline R4259/C & .88 & 0.32 & 0.22 & 0.18 & 1.30 & - & 0.05 & 3.3 & 33 \\
\hline R4260/C & 1.00 & 0.30 & 0.38 & .050 & 1.70 & - & 0.08 & 5.0 & 46 \\
\hline R4261/C & 0.97 & 0.29 & 0.23 & 0.34 & 3.90 & - & 0.08 & 6.4 & 52 \\
\hline R4262/NC & 0.24 & 0.06 & 0.14 & 0.32 & 0.81 & - & 0.02 & 2.2 & 20 \\
\hline R4263/NC & 1.40 & 0.37 & 0.47 & 0.24 & 0.79 & - & 0.08 & 3.5 & 32 \\
\hline R4264/NC & & & & & & & & & \\
\hline
\end{tabular}

$\begin{array}{ll}\text { (a) } & \text { Derivatization performed in fume hood } \\ \text { (b) } & \text { Assuming response similar to EDTA } \\ \text { (c) } & \text { HEDTA was found in window E composite samples, but not in the segment subsamples } \\ \text { (o) } & \text { Total includes minor components not included in this summary table } \\ \text { (e) } & \text { Sample analysis in progress } \\ \text { C } & \text { Convective layer } \\ \text { CA } & \text { citric acid } \\ \text { ED3A } & \text { ethylenediaminetriacetic acid } \\ \text { EDTA } & \text { ethylenediaminetetraacetic acid } \\ \text { GC/MS } & \text { Gas chromatograph/mass spectrometer } \\ \text { HEDTA } & \text { N-(2-hydroxyethly)ethylenediaminetriacetic acid } \\ \text { NC } & \text { Nonconvective layer } \\ \text { NIDA } & \text { nitrilotriacetic acid } \\ \text { NTA } & \text { nitrilotriacetic acid } \\ \text { SA } & \text { succinic acid } \\ \text { TOC } & \text { Total organic carbon. }\end{array}$


Table A-2. LC Results for Oxalate, Formic, Glycolic, and Acetic Acids (mg Carbon/g Sample) for 241-SY-101 Window E Core Segment Samples

\begin{tabular}{|l|r|r|r|r|r|c|}
\hline Sample \# & Oxalic & Glycolic & Acetic & Formic & Total & $\begin{array}{c}\text { Percent TOC } \\
\text { Accounted for }\end{array}$ \\
\hline R4258/C & 1.7 & 0.6 & & 1.1 & 3.3 & 30 \\
\hline R4259/C & 2.0 & 0.43 & 0.81 & 1.4 & 4.5 & 44 \\
\hline R4260/C & 1.8 & 0.6 & & 1.9 & 4.4 & 41 \\
\hline R4261/C & 1.6 & & & 1.0 & 2.5 & 23 \\
\hline R4262/NC & 5.0 & & & 0.87 & 5.8 & 53 \\
\hline R4263/NC & 6.4 & & & 0.37 & 6.8 & 61 \\
\hline R4264/NC(a) & & & & & & \\
\hline
\end{tabular}

(a) Sample analysis in progress

$\mathrm{C}$ Convective layer

NC Nonconvective layer. 
WHC-SD-WM-ES-321

Revision 0

This page intentionally left blank. 